\title{
O COMEÇO DA HISTÓRIA. \\ A NOVA INTERPRETAÇÃO CONSTITUCIONAL E O PAPEL DOS PRINCÍPIOS NO DIREITO BRASILEIRO'
}

\author{
LUÍS ROBERTO BARROSO* \\ ANA PAULA DE BARCELlOS**
}

\begin{abstract}
Introdução: A pré-história constitucional brasileira. - Parte I: A nova interpretação constitucional - I. Tradição e modernidades: uma nota explicativa - II. Pós-positivismo e a ascensão dos princípios - III. Princípios e regras, ainda uma vez - IV. Ponderação de interesses, valores e normas - V. Teoria da argumentação - Parte II: Princípios constitucionais - I. Princípios instrumentais de interpretação constitucional - Il. Princípios constitucionais materiais: uma classificaçāo - III. As modalidades de eficácia dos princípios - IV. Algumas aplicaçōes concretas dos princípios materiais. Conclusão.
\end{abstract}

\section{INTRODUÇÃO \\ A PRÉ-HISTÓRIA CONSTITUCIONAL BRASILEIRA}

A experiência política e constitucional do Brasil, da independência até 1988, é a melancólica história do desencontro de um país com sua gente e com seu destino. Quase dois séculos de ilegitimidade renitente do poder, de falta de efetividade das múltiplas Constituições e de uma infindável sucessão de violações da legalidade constitucional. Um acúmulo de gerações perdidas.

1 Este trabalho é dedicado a Raymundo Faoro. No geral, pelo papel que desempenhou na transição democrática brasileira. No particular, por ter ajudado a evitar que estudantes da UERJ sofressem violências no Departamento de Polícia Política e Social — DPPS, no final da década de 70.

* Professor Titular de Direito Constitucional da Universidade do Estado do Rio de Janeiro. Mestre em Direito pela Universidade de Yale.

** Professora Assistente de Direito Constitucional da UERJ. Mestre em Direito. 
A ilegitimidade ancestral materializou-se na dominação de uma elite de visão estreita, patrimonialista, que jamais teve um projeto de país para toda a gente ${ }^{2}$. Viciada pelos privilégios e pela apropriação privada do espaço público, produziu uma sociedade com deficit de educação, de saúde, de saneamento, de habitação, de oportunidades de vida digna. Uma legião imensa de pessoas sem acesso à alimentação adequada, ao consumo e à civilização, em um país rico, uma das maiores economias do mundo.

A falta de efetividade das sucessivas Constituições brasileiras decorreu do não reconhecimento de força normativa aos seus textos e da falta de vontade política de dar-lhes aplicabilidade direta e imediata ${ }^{3}$. Prevaleceu entre nós a tradição européia da primeira metade do século, que via a Lei Fundamental como mera ordenação de programas de ação, convocaçôes ao legislador ordinário e aos poderes públicos em geral. Daí porque as Cartas brasileiras sempre se deixaram inflacionar por promessas de atuação e pretensos direitos que jamais se consumaram na prática. Uma história marcada pela insinceridade e pela frustração.

O desrespeito à legalidade constitucional acompanhou a evolução política brasileira como uma maldição, desde que D. Pedro I dissolveu a primeira Assembléia Constituinte. Das rebeliões ao longo da Regência ao golpe republicano, tudo sempre prenunciou um enredo acidentado, onde a força bruta diversas vezes se impôs sobre o Direito. Foi assim com Floriano Peixoto, com o golpe do Estado Novo, com o golpe militar, com o impedimento de Pedro Aleixo, com os Atos Institucionais. Intolerância, imaturidade e insensibilidade social derrotando a Constituição.

Um país que não dava certo.

A Constituição de 1988 foi o marco zero de um recomeço, da perspectiva de uma nova história. Sem as velhas utopias, sem certezas ambiciosas, com o caminho a ser feito ao andar. Mas com uma carga de esperança e um lastro de legitimidade sem precedentes, desde que tudo começou. E uma novidade. Tardiamente, o povo ingressou na trajetória política brasileira, como protagonista do processo, ao lado da velha aristocracia e da burguesia emergente.

Nessa história ainda em curso, e sem certeza de final feliz, é fato, quanto à ilegitimidade ancestral, que a elite já não conserva a onipotência e a insensibilidade da antiga plutocracia. Seus poderes foram atenuados por fenômenos políticos importantes, como a organização da sociedade, a liberdade de imprensa, a formação de uma opinião pública mais consciente, o movimento social e, já agora. a alternância do poder.

A legalidade constitucional, a despeito da compulsão com que se emenda a Constituição, vive um momento de elevação: quinze anos sem ruptura, um verdadeiro

2 Sobre o tema v. Raymundo FAORO. Os donos do poder, 2000 (a $1^{\text {a }}$ edição é de 1957).

3 Sobre o conceito de "força normativi" v. Konrad HESSE. A força normativa da Constituição, 1991 (trata-se da aula inaugural proferida por Konrad HESSE na Universidade de Freiburg em 1959). V. também, sobre o tema: José Afonso da SILVA, Aplicabilidade das normas constitucionais, 1998 ( $\mathrm{l}^{\mathrm{a}}$ edição de 1969 ) e Luís Roberto Barroso, O direito constitucional e a efetividade de suas normas, 2002. 
recorde em um país de golpes e contra-golpes. Ao longo desse período, destituiu-se um Presidente, afastaram-se Senadores e chegou ao poder um partido de esquerda, sem que uma voz sequer se manifestasse pelo desrespeito às regras constitucionais. Nessa saudável transformação, não deve passar despercebido o desenvolvimento de uma nova atitude e de uma nova mentalidade nas Forças Armadas.

E a efetividade da Constituição, rito de passagem para o início da maturidade institucional brasileira, tornou-se uma idéia vitoriosa e incontestada. As normas constitucionais conquistaram o status pleno de normas juridicas, dotadas de imperatividade, aptas a tutelar direta e imediatamente todas as situações que contemplam. Mais do que isso, a Constituição passa a ser a lente através da qual se lêem e se interpretam todas as normas infraconstitucionais. A Lei Fundamental e seus princípios deram novo sentido e alcance ao direito civil, ao direito processual, ao direito penal, enfim, a todos os demais ramos jurídicos ${ }^{4}$. A efetividade da Constituição é a base sobre a qual se desenvolveu, no Brasil, a nova interpretação constitucional ${ }^{5}$.

A seguir, expõem-se algumas idéias a propósito dessa fase de efervescente criatividade na dogmática jurídica e de sua aproximação com a ética e com a realização dos direitos fundamentais. O debate é universal, mas a perspectiva é brasileira. Um esforço de elaboração teórica a serviço dos ideais de avanço social e de construção de um país justo e digno. Que possa derrotar o passado que não soube ser.

\section{PARTE I \\ A NOVA INTERPRETAÇÃO CONSTITUCIONAL}

\section{Tradição e modernidades: uma nota explicativa}

A idéia de uma nova interpretação constitucional liga-se ao desenvolvimento de algumas fórmulas originais de realização da vontade da Constituição. Não importa em desprezo ou abandono do método clássico - o subsuntivo ${ }^{6}$, fundado na aplicação de regras - nem dos elementos tradicionais da hermenêutica: gramatical, histórico, sistemático e teleológico. Ao contrário, continuam eles a desempenhar um papel

4 O direito civil, em especial, tem desenvolvido todia uma nova perspectiva de estudo a partir da Constituição. V., dentre outros, Gustavo TEPEDINO (coord.), A parte geral do novo Código Civil. Estudos na perspectiva civil-constitucional, 2002; Luiz Edson FACHIN, Repensando os fundamentos do direito civil, 1998; Judith Martins-COSTA (org.), A reconstruçăo do direito privado, 2002; Renan LOTUFO (coord.), Direito civil constitucional, cad. 3, 2002.

5 Sobre o tema, Luís Roberto BARROSO, O direito constitucional e a efetividade de suas nomas, 2002.

6 Nessa perspectiva, a interpretação jurídica consiste em um processo silogístico de subsunção dos fatos à norma: a lei é a premissa maior, os fatos são a premissa menor e a sentença é a conclusāo. O papel do juiz consiste em revelar a vontade da norma, desempenhando uma atividade de mero conhecimento, sem envolver qualquer parcela de criação do Direito para o caso concreto. 
relevante na busca de sentido das normas e na solução de casos concretos ${ }^{7}$. Relevante, mas nem sempre suficiente.

Mesmo no quadro da dogmática jurídica tradicional, já haviam sido sistematizados diversos princípios específicos de interpretação constitucional, aptos a superar as limitações da interpretação jurídica convencional, concebida sobretudo em função da legislação infraconstitucional, e mais especialmente do direito civil. A grande virada na interpretação constitucional se deu a partir da difusão de uma constatação que, além de singela, sequer era original: não é verdadeira a crença de que as normas jurídicas em geral - e as normas constitucionais em particular - tragam sempre em si um sentido único, objetivo, válido para todas as situações sobre as quais incidem. E que, assim, caberia ao intérprete uma atividade de mera revelação do conteúdo pré-existente na norma, sem desempenhar qualquer papel criativo na sua concretização.

A nova interpretação constitucional assenta-se no exato oposto de tal proposição: as cláusulas constitucionais, por seu conteúdo aberto, principiológico e extremamente dependente da realidade subjacente, não se prestam ao sentido unívoco e objetivo que uma certa tradição exegética lhes pretende dar. O relato da norma, muitas vezes, demarca apenas uma moldura dentro da qual se desenham diferentes possibilidades interpretativas. À vista dos elementos do caso concreto, dos princípios a serem preservados e dos fins a serem realizados é que será determinado o sentido da norma, com vistas à produção da solução constitucionalmente adequada para o problema a ser resolvido.

Antes de avançar no tema, cabe ainda uma nota de advertência. Muitas situações subsistem em relação às quais a interpretação constitucional envolverá uma operação intelectual singela, de mera subsunção de determinado fato à norma. Tal constatação é especialmente verdadeira em relação à Constituição brasileira, povoada de regras de baixo teor valorativo, que cuidam do varejo da vida. Alguns exemplos de normas que, de ordinário, não dão margem a maiores especulações teóricas: (i) implementada a idade para a aposentadoria compulsória, o servidor público deverá passar para a inatividade (CF, art. $\left.40, \S 1^{\circ}, \mathrm{II}\right)$; (ii) o menor de trinta e cinco anos não é elegível para o cargo de Senador da República (CF, art. $14, \S 3^{\circ}, \mathrm{VI}, a$ ); (iii) não é possível o divórcio antes de um ano da separação judicial (CF, art. $226, \S 6^{\circ}$ ).

Portanto, ao se falar em nova interpretação constitucional, normatividade dos princípios, ponderação de valores, teoria da argumentação, não se está renegando o conhecimento convencional, a importância das regras ou a valia das soluções subsuntivas. Embora a história das ciências se faça, por vezes, em movimentos revolucionários de ruptura, não é disso que se trata aqui. A nova interpretação constitucional é fruto de evolução seletiva, que conserva muitos dos conceitos tradicionais, aos

7 Sobre esta temática, vejam-se no direito brasileiro, dentre outros, Luís Roberto BARROSO, Interpretaçāo e aplicação da Constituição, 2003 (a la edição é de 1995), Juarez de FREITAS, $A$ interpretação sistemática do direito, 2002 (a lª edição é de 1995) e Inocêncio Mártires COELHO, Interpretação constitucional, 1997. 
quais, todavia, agrega idéias que anunciam novos tempos e acodem a novas demandas.

No fluxo das modernidades aqui assinaladas, existem técnicas, valores e personagens que ganharam destaque. E outros que, sem desaparecerem, passaram a dividir o palco, perdendo a primazia do papel principal. Um bom exemplo: a norma, na sua dicção abstrata, já não desfruta da onipotência de outros tempos. Para muitos, não se pode sequer falar da existência de norma antes que se dê a sua interação com os fatos, tal como pronunciada por um intérprete ${ }^{8}$. É claro que os fatos e o intérprete sempre estiveram presentes na interpretação constitucional. Mas nunca como agora. Faça-se uma anotação sumária sobre cada um:

(i) Os fatos subjacentes e as conseqüências práticas da interpretação. Em diversas situações, inclusive e notadamente nas hipóteses de colisão de normas e de direitos constitucionais, não será possível colher no sistema, em tese, a solução adequada: ela somente poderá ser formulada à vista dos elementos do caso concreto, que permitam afirmar qual desfecho corresponde à vontade constitucional ${ }^{9}$. Ademais, o resultado do processo interpretativo, seu impacto sobre a realidade não pode ser desconsiderado ${ }^{10}$ : é preciso saber se o produto da incidência da norma sobre o fato realiza finalisticamente o mandamento constitucional ".

(ii) O intérprete e os limites de sua discricionariedade. A moderna interpretação constitucional envolve escolhas pelo intérprete, bem como a integração subjetiva de princípios, normas abertas e conceitos indeterminados. Boa parte da produção científica da atualidade tem sido dedicada, precisamente, à contenção da discricionariedade judicial, pela demarcação de parâmetros para a ponderação de valores e interesses e pelo dever de demonstração fundamentada da racionalidade e do acerto de suas opções.

8 A não identidade entre norma e texto normativo, entre o "programa normativo" (correspondente ao comando jurídico) e o "domínio normativo" (a realidade social), é postulado básico da denominada metódica "normativo-estruturante" de Friedrich MÚLLER (Discourse de la méthode juridique, 1996; a $1^{\text {a }}$. ed. do original Juristische Methodik é de 1993). Sobre o tema, v. tb. J. J. Gomes CANOTILHO, Direito constitucional e teoria da Constituição, 2001, p. 1.179.

9 Qual o bem jurídico de maior valia: a liberdade de expressão ou a liberdade de ir e vir? Quando será legítima uma manifestação política que paralise o trânsito em uma via pública? Se for o comício de encerramento da campanha presidencial do candidato de um partido político nacional, parece razoável. Mas se vinte estudantes secundaristas deitarem-se ao longo de uma larga avenida, em protesto contra a qualidade da merenda, seria uma manifestação legítima?

10 Eduardo García de ENTERRfA, La constitucion como norma y el tribunal constitucional, 1994, p. 183 e ss..

11 Pode acontecer que uma norma, sendo constitucional no seu relato abstrato, produza um resultado inconstitucional em uma determinada incidência. Por exemplo: o STF considerou constitucional a lei que impede a concessão de antecipação de tutela contra a Fazenda Pública (RTJ 169:383, ADC-MC 4, Rel. Min. Sydney Sanches), fato que, todavia, não impediu um Tribunal de Justiça de concedê-la, porque a abstenção importaria no sacrifício do direito à vida da requerente (AI 598.398.600, TJRS, 4². CC, Rel. Des. Araken de Assis). Veja-se o comentário dessa decisão em Ana Paula ÁVILA, Razoabilidade, proteção do direito fundamental à saúde e antecipação da tutela contra a Fazenda Pública, Ajuris 86/361. 
Feita a advertência. passa-se à discussão de alguns dos temas que têm mobilizado o universo acadêmico nos últimos tempos e que, mais recentemente, vêm migrando para a dogmática jurídica e para a prática jurisprudencial.

\section{Pós-positivismo e a ascensão dos principios ${ }^{12}$}

O jusnaturalismo moderno, que começou a formar-se a partir do século XVI, dominou por largo período a filosofia do Direito. A crença no direito natural — isto é, na existência de valores e de pretensões humanas legítimas que não decorrem de uma norma emanada do Estado - foi um dos trunfos ideológicos da burguesia e o combustível das revoluções liberais. Ao longo do século XIX, com o advento do Estado liberal, a consolidação dos ideais constitucionais em textos escritos e o êxito do movimento de codificação, o jusnaturalismo chega ao seu apogeu e, paradoxalmente, tem início a sua superação histórica. Considerado metafísico e anticientífico, o direito natural é empurrado para a margem da história pela onipotência positivista do final século XIX ${ }^{13}$.

O positivismo filosófico foi fruto de uma crença exacerbada no poder do conhecimento científico. Sua importação para o Direito resultou no positivismo jurídico, na pretensão de criar-se uma ciência jurídica, com características análogas às ciências exatas e naturais. A busca de objetividade científica, com ênfase na realidade observável e não na especulação filosófica, apartou o Direito da moral e dos valores transcendentes. Direito é norma, ato emanado do Estado com caráter imperativo e força coativa. A ciência do Direito, como todas as demais, deve fundar-se em juízos de fato, que visam ao conhecimento da realidade, e não em juízos de valor, que representam uma tomada de posição diante da realidade. Não é no âmbito do Direito que se deve travar a discussão acerca de questões como legitimidade e justiça ${ }^{14}$.

Sem embargo da resistência filosófica de outros movimentos influentes nas primeiras décadas do século $\mathrm{XX}^{15}$, a decadência do positivismo é emblematicamente

12 Sobre o tema, v. Luís Roberto BARROSO, "Fundamentos teóricos e filosóficos do novo direito constitucional brasileiro (pós-modernidade, teoria crítica e pós-positivismo)", in Temas de direito constitucional, t. II, p. 3 e ss.

13 Bobbio, Matteucci e Pasquino, Dicionário de política, 1986, p. 659; Ana Paula de BARCELLOS, As relações da filosofia do direito com a experiência jurídica. Uma visão dos séculos XVIII, $X I X$ e XX. Algumas questōes atuais, Revista Forense 351/10; e Viviane Nunes Araújo LIMA, A saga do zangão: uma visão sobre o direito natural. 2000, p. 181.

14 BOBBIO, V. Norberto. O positivismo jurídico, 1995, p. 223-4, e também LÖWY, Michael, Ideologias e ciência social - elementos para uma análise marxista, 1996, p. 40: "O positivismo, que se apresenta como ciência livre de juízos de valor, neutra, rigorosamente científica, (...) acaba tendo uma função política e ideológica".

15 Como por exemplo, a jurisprudencia dos interesses, iniciada por IHERINg, e o movimento pelo direito livre, no qual se destacou Ehrlich. 
associada à derrota do fascismo na Itália e do nazismo na Alemanha. Esses movimentos políticos e militares ascenderam ao poder dentro do quadro de legalidade vigente e promoveram a barbárie em nome da lei. Os principais acusados de $\mathrm{Nu}$ remberg invocaram o cumprimento da lei e a obediência a ordens emanadas da autoridade competente. Ao fim da Segunda Guerra Mundial, a idéia de um ordenamento jurídico indiferente a valores éticos e da lei como uma estrutura meramente formal, uma embalagem para qualquer produto, já não tinha mais aceitação no pensamento esclarecido ${ }^{16}$.

A superação histórica do jusnaturalismo e o fracasso político do positivismo abriram caminho para um conjunto amplo e ainda inacabado de reflexões acerca do Direito, sua função social e sua interpretação. O pós-positivismo é a designação provisória e genérica de um ideário difuso, no qual se incluem a definição das relações entre valores, princípios e regras, aspectos da chamada nova hermenêutica constitucional, e a teoria dos direitos fundamentais ${ }^{17}$, edificada sobre o fundamento da dignidade humana. A valorização dos princípios, sua incorporação, explícita ou implícita, pelos textos constitucionais e o reconhecimento pela ordem jurídica de sua normatividade fazem parte desse ambiente de reaproximação entre Direito e Ética.

Gradativamente, diversas formulações antes dispersas ganham unidade e consistência, ao mesmo tempo em que se desenvolve o esforço teórico que procura transformar o avanço filosófico em instrumental técnico-jurídico aplicável aos problemas concretos. $O$ discurso acerca dos princípios, da supremacia dos direitos fundamentais e do reencontro com a Ética - ao qual, no Brasil, se deve agregar o da transformação social e o da emancipação - deve ter repercussão sobre o ofício dos juízes, advogados e promotores, sobre a atuação do Poder Público em geral e sobre a vida das pessoas. Trata-se de transpor a fronteira da reflexão filosófica, ingressar na dogmática jurídica e na prática jurisprudencial e, indo mais além, produzir efeitos positivos sobre a realidade. Os tópicos que se seguem têm a ambição de servir de guia elementar para a construção da normatividade e da efetividade do pós-positivismo.

\section{Principios e regras, ainda uma vez}

$\mathrm{Na}$ trajetória que os conduziu ao centro do sistema, os princípios tiveram de conquistar o status de norma jurídica, superando a crença de que teriam uma dimen-

16 NINO, Carlos Santiago, Etica y derechos humanos, 1989, p. 3 e ss.; e Ricardo Lobo TORRES, Os direitos humanos e a tributação - imunidades e isonomia, 1995, p. 6 e ss..

17 Sobre o tema, vejam-se: Antônio Augusto Cançado TRINDADE, A proteção internacional dos direitos humanos: fundamentos jurídicos e instrumentos básicos, 1991; Ingo Wolfgang SARLET, A eficácia dos direitos fundamentais, 1998; Flávia PIOVESAN, Temas de direitos humanos, 1998; Ricardo Lobo TORRES (org.), Teoria dos direitos fundamentais, 1999; Willis Santiago GUERRA FILHO, Processo constitucional e direitos fundamentais, 1999; e Gilmar Ferreira MENDES, Inocêncio Mártires COELHO e Paulo Gustavo Gonet BRANCO, Hermenêutica constitucional e direitos fundamentais, 2000. 
são puramente axiológica, ética, sem eficácia jurídica ou aplicabilidade direta e imediata. A dogmática moderna avaliza o entendimento de que as normas em geral, e as normas constitucionais em particular, enquadram-se em duas grandes categorias diversas: os princípios e as regras. Antes de uma elaboração mais sofisticada da teoria dos princípios, a distinção entre eles fundava-se, sobretudo, no critério da generalidade $^{18}$. Normalmente, as regras contêm relato mais objetivo, com incidência restrita às situações específicas às quais se dirigem. Já os princípios têm maior teor de abstração e incidem sobre uma pluralidade de situações. Inexiste hierarquia entre ambas as categorias, à vista do princípio da unidade da Constituição. Isto não impede que princípios e regras desempenhem funções distintas dentro do ordenamento.

Nos últimos anos, todavia, ganhou curso generalizado uma distinção qualitativa ou estrutural entre regra e princípio, que veio a se tornar um dos pilares da moderna dogmática constitucional, indispensável para a superação do positivismo legalista, onde as normas se cingiam a regras jurídicas ${ }^{19}$. A Constituição passa a ser encarada como um sistema aberto de princípios e regras, permeável a valores jurídicos suprapositivos, no qual as idéias de justiça e de realização dos direitos fundamentais desempenham um papel central. A mudança de paradigma nessa matéria deve especial tributo às concepçōes de Ronald DWORKIN ${ }^{20}$ e aos desenvolvimentos a ela dados por Robert Alexy ${ }^{21}$. A conjugação das idéias desses dois autores dominou a teoria jurídica e passou a constituir o conhecimento convencional na matéria 22 .

Regras são, normalmente, relatos objetivos, descritivos de determinadas condutas e aplicáveis a um conjunto delimitado de situações. Ocorrendo a hipótese prevista no seu relato, a regra deve incidir, pelo mecanismo tradicional da subsunção: enquadram-se os fatos na previsão abstrata e produz-se uma conclusão. A aplicação de uma regra se opera na modalidade tudo ou nada: ou ela regula a matéria em sua inteireza ou é descumprida. Na hipótese do conflito entre duas regras, só uma será válida e irá prevalecer ${ }^{23}$. Princípios, por sua vez, contêm relatos com maior grau de

18 ESSER, Josef, Principio y norma en la elaboración jurisprudencial del derecho privado, 1961, p. 66 .

19 Rodolfo L. Vigo, Los principios jurídicos - perspectiva jurisprudencial, 2000, p. 9/20. O autor apresenta um interessante panorama dos critérios distintivos entre princípios e regras já propostos pela doutrina.

20 DWORKIN, Ronald, Taking rights seriously, 1997 (a 1". edição é de 1977). O texto seminal nessa matéria, do próprio DWORKIN, foi "The model of rules". University of Chicago Law Review, 35/14 (1967).

21 ALEXY, Robert, Teoria de los derechos fundamentales, 1997 (a 1". ed. do original Theorie der Grundrechte é de 1986).

22 O consenso vem sendo, todavia, progressivamente rompido pelo surgimento de trabalhos críticos de qualidade. V. na doutrina nacional, Humberto ÁVILA, Teoria dos princípios (da definição à aplicação dos princ(pios jurldicos), 2003, mimeografado (livro no prelo, original gentilmente cedido pelo autor); na doutrina estrangeira, Klaus GUNTHER. The sense of appropriateness Application discourses in morality and law. 1993. Para uma defesa das posições de Alexy, v. Thomas da Rosa BUSTAMANTE, $A$ distinção estrutural entre princtpios e regras e sua importância para a dogmática jurídica, 2003, mimeografado (original gentilmente cedido pelo autor).

23 V Luís Roberto BARROSO, "Fundamentos teóricos e filosóficos do novo direito constitucional brasileiro", in Temas de direito constitucional, t. II, p. 32: "O Direito, como se sabe, é um sistema 
abstração, não especificam a conduta a ser seguida e se aplicam a um conjunto amplo, por vezes indeterminado, de situações. Em uma ordem democrática, os princípios frequientemente entram em tensão dialética, apontando direções diversas. Por essa razão, sua aplicação deverá se dar mediante ponderação: à vista do caso concreto, o intérprete irá aferir o peso que cada princípio deverá desempenhar na hipótese, mediante concessões recíprocas, e preservando o máximo de cada um, na medida do possível. Sua aplicação, portanto, não será no esquema tudo ou nada, mas graduada à vista das circunstâncias representadas por outras normas ou por situações de fato ${ }^{24}$.

Pois bem: ultrapassada a fase de um certo deslumbramento com a redescoberta dos princípios como elementos normativos, o pensamento jurídico tem se dedicado à elaboração teórica das dificuldades que sua interpretação e aplicação oferecem, tanto na determinação de seu conteúdo quanto no de sua eficácia. A ênfase que se tem dado à teoria dos princípios deve-se, sobretudo, ao fato de ser nova e de apresentar problemas ainda irresolvidos. O modelo tradicional, como já mencionado, foi concebido para a interpretação e aplicação de regras. É bem de ver, no entanto, que o sistema jurídico ideal se consubstancia em uma distribuição equilibrada de regras e princípios, nos quais as regras desempenham o papel referente à segurança jurídica - previsibilidade e objetividade das condutas - e os princípios, com sua flexibilidade, dão margem à realização da justiça do caso concreto ${ }^{25}$.

de normas harmonicamente articuladas. Uma situação não pode ser regida simultaneamente por duas disposições legais que se contraponham. Para solucionar essas hipóteses de conflito de leis, o ordenamento jurídico se serve de três critérios tradicionais: o da hierarquia - pelo qual a lei superior prevalece sobre a inferior - o cronológico - onde a lei posterior prevalece sobre a anterior - e o da especialização - em que a lei específica prevalece sobre a lei geral. Estes critérios, todavia, não são adequados ou plenamente satisfatórios quando a colisão se dá entre normas constitucionais, especialmente entre princípios constitucionais, categoria na qual devem ser situados os conflitos entre direitos fundamentais."

24 ALEXY, Robert, Teoria de los derechos fundamentales, 1997, p. 86: "Princípios são normas que ordenam que algo seja realizado na maior medida possível, dentro das possibilidades jurídicas e reais existentes. Por isso, são mandados de otimização, caracterizados pelo fato de que podem ser cumpridos em diferentes graus e que a medida devida de seu cumprimento não só depende das possibilidades reais, mas também das jurídicas. $O$ âmbito do juridicamente possível é determinado pelos princípios e regras opostas."

25 V. Ana Paula de Barcellos, Ponderação de normas: alguns parâmetros jurídicos, projeto de tese de doutoramento aprovado no programa de Pós-graduação em Direito Público da Universidade do Estado do Rio de Janeiro: "E possível identificar uma relação entre a segurança, a estabilidade e a previsibilidade e as regras jurídicas. Isso porque, na medida $\mathrm{em}$ que veiculam efeitos jurídicos determinados, pretendidos pelo legislador de forma específica, as regras contribuem para a maior previsibilidade do sistema jurídico. A justiça, por sua vez, depende em geral de normas mais flexíveis, à maneira dos princípios, que permitam uma adaptação mais livre às infinitas possibilidades do caso concreto e que sejam capazes de conferir ao intérprete liberdade de adaptar o sentido geral do efeito pretendido, muitus vezes impreciso e indeterminado, às peculiaridades da hipótese examinada. Nesse contexto, portanto, os princípios são espécies normativas que se ligam de modo mais direto à idéia de justiça. Assim, como esquema geral, é possível dizer que a estrutura das regras facilita a realização do valor segurança, ao passo que os princípios oferecem melhores condições para que a justiça possa ser alcançada" (texto ligeiramente editado). 
É de proveito aprofundar o tema da distinção entre princípios e regras, especialmente no que diz respeito às potencialidades que oferecem para a atuação do intérprete constitucional. Sem embargo da multiplicidade de concepf̧ões na matéria, há pelo menos um consenso sobre o qual trabalha a doutrina em geral: princípios e regras desfrutam igualmente do status de norma jurídica e integram, sem hierarquia, o sistema referencial do intérprete. Dos múltiplos critérios distintivos possíveis ${ }^{26}$, três deles são aqui destacados: (i) o conteúdo; (ii) a estrutura normativa; (iii) as particularidades da aplicação.

Quanto ao contéido, destacam-se os princípios como normas que identificam valores a serem preservados ou fins a serem alcançados. Trazem em si, normalmente, um conteúdo axiológico ou uma decisão política. Isonomia, moralidade, eficiência são valores. Justiça social, desenvolvimento nacional, redução das desigualdades regionais são fins públicos. Já as regras limitam-se a traçar uma conduta. A questão relativa a valores ou a fins públicos não vem explicitada na norma porque já foi decidida pelo legislador, e não transferida ao intérprete. Daí ser possível afirmar-se que regras são descritivas de conduta, ao passo que princípios são valorativos ou finalísticos.

Com relação à estrutura normativa, tem-se que o relato de uma regra especifica os atos a serem praticados para seu cumprimento adequado. Embora a atividade do intérprete jamais possa ser qualificada como mecânica — pois a ele cabe dar o toque de humanidade que liga o texto à vida real -, a aplicação de uma regra normalmente não envolverá um processo de racionalização mais sofisticado. Se ocorre o fato previsto em abstrato, produz-se o efeito concreto prescrito. Já os princípios indicam fins, estados ideais a serem alcançados. Como a norma não detalha a conduta a ser seguida para sua realização, a atividade do intérprete será mais complexa, pois a ele caberá definir a ação a tomar.

Pode ocorrer ainda, em relação aos princípios, uma dificuldade adicional: o fim a ser atingido ou o estado ideal a ser transformado em realidade pode não ser objetivamente determinado, envolvendo uma integração subjetiva por parte do intérprete. Um princípio tem um sentido e alcance mínimos, um núcleo essencial, no qual se equiparam às regras. A partir de determinado ponto, no entanto, ingressa-se em um espaço de indeterminação, no qual a demarcação de seu conteúdo estará sujeita à concepção ideológica ou filosófica do intérprete. Um exemplo é fornecido pelo princípio da dignidade da pessoa humana. Além de não explicitar os comportamentos necessários para realizar a dignidade humana - esta, portanto, é a primeira dificuldade: descobrir os comportamentos - poderá haver controvérsia sobre o que significa a própria dignidade a partir de um determinado conteúdo essencial, conforme o ponto de observação do intérprete ${ }^{27}$.

26 Sobre o tema, vejam-se Karl LARENZ, Metodologia da ciência do direito, 1997; Claus-Wilhelm CANARIS.Pensamento sistemático e conceito de sistema na ciência do direito, 1996. Na doutrina brasileira. v. o importante estudo de Humberto ÁVILA, Teoria dos princípios (da definição à aplicação dos princípios jurídicos), cit.

27 Essa característica dos princípios, aliás, é que permite que a norma se adapte, ao longo do tempo, a diferentes realidades, além de permitir a concretização do princípio da maioria, inerente ao regime 
Quanto ao modo ou particularidades de sua aplicação, a doutrina que se desenvolveu sobre as premissas teóricas de Dworkin e Alexy traça a distinção entre princípios e regras na forma já registrada acima e que se reproduz sumariamente, para fins de encadeamento do raciocínio. Regras são proposições normativas aplicáveis sob a forma de tudo ou nada ("all or nothing"). Se os fatos nela previstos ocorrerem, a regra deve incidir, de modo direto e automático, produzindo seus efeitos. Uma regra somente deixará de incidir sobre a hipótese de fato que contempla se for inválida, se houver outra mais específica ou se não estiver em vigor. Sua aplicação se dá, predominantemente, mediante subsunção.

Princípios contêm, normalmente, uma maior carga valorativa, um fundamento ético, uma decisão política relevante, e indicam uma determinada direção a seguir. Ocorre que, em uma ordem pluralista, existem outros princípios que abrigam decisões, valores ou fundamentos diversos, por vezes contrapostos. A colisão de princípios, portanto, não só é possível, como faz parte da lógica do sistema, que é dialético. Por isso a sua incidência não pode ser posta em termos de tudo ou nada, de validade ou invalidade. Deve-se reconhecer aos princípios uma dimensão de peso ou importância. À vista dos elementos do caso concreto, o intérprete deverá fazer escolhas fundamentadas, quando se defronte com antagonismos inevitáveis, como os que existem entre a liberdade de expressão e o direito de privacidade, a livre iniciativa e a intervenção estatal, o direito de propriedade e a sua função social. A aplicação dos princípios se dá, predominantemente, mediante ponderação ${ }^{28}$.

É certo que, mais recentemente, já se discute tanto a aplicação do esquema tudo ou nada aos princípios como a possibilidade de também as regras serem ponderadas. Isso porque, como visto, determinados princípios - como o princípio da dignidade da pessoa humana e outros - apresentam um núcleo de sentido ao qual se atrịui natureza de regra, aplicável biunivocamente ${ }^{29}$. Por outro lado, há situações em que uma regra, perfeitamente válida em abstrato, poderá gerar uma inconstitucionalidade ao incidir em determinado ambiente ou, ainda, há hipóteses em que a adoção do

democrático. Há um sentido mínimo, oponível a qualquer grupo que venha a exercer o poder, e também um espaço cujo conteúdo será preenchido pela deliberação democrática.

28 Partindo da idéia original de DWORKIN, o autor alemão Robert ALEXY (Teoria de los derechos fundamentales, 1997, p. 81 e ss.) deu novos desenvolvimentos analíticos ao tema, nos termos a seguir resumidos. As regras veiculam mandados de definição, ao passo que os princípios são mandados de otimização. Por essas expressões se quer significar que as regras (mandados de definição) têm natureza biunívoca, isto é, só admitem duas espécies de situação, dado seu substrato fático típico: ou são válidas e se aplicam ou não se aplicam por inválidas. Uma regra vale ou não vale juridicamente. Não são admitidas gradações. A exceção da regra ou é outra regra, que invalida a primeira, ou é a sua violação.

Os princípios se comportam de maneira diversa. Como mandados de otimização, pretendem eles ser realizados da forma mais ampla possível, admitindo, entretanto, aplicação mais ou menos intensa de acordo com as possibilidades jurídicas existentes, sem que isso comprometa sua validade. Esses limites jurídicos, capazes de restringir a otimização do princípio, são (i) regras que o excepcionam em algum ponto e (ii) outros princípios de mesma estatura e opostos que procuram igualmente maximizar-se, impondo a necessidade eventual de ponderação.

29 BARCELLOS, Ana Paula de. A eficácia jurídica dos princípios constitucionais. O princípio da dignidade da pessoa humana, 2002, p. 191 e ss. 
comportamento descrito pela regra violará gravemente o próprio fim que ela busca alcançar ${ }^{30}$. Esses são fenômenos de percepção recente, que começam a despertar o interesse da doutrina, inclusive e sobretudo por seu grande alcance prático.

Princípios - e, com crescente adesão na doutrina, também as regras - são ponderados, à vista do caso concreto. E, na determinação de seu sentido e na escolha dos comportamentos que realizarão os fins previstos, deverá o intérprete demonstrar o fundamento racional que legitima sua atuação. Chega-se, assim, aos dois temas que se seguem: a ponderação e a argumentação jurídica.

\section{Ponderação de interesses, bens, valores e normas ${ }^{31}$}

Durante muito tempo, a subsunção foi a única fórmula para compreender a aplicação do direito, a saber: premissa maior - a norma - incidindo sobre a premissa menor - os fatos - e produzindo como consequiência a aplicação do conteúdo da norma ao caso concreto. Como já se viu, essa espécie de raciocínio continua a ser fundamental para a dinâmica do direito. Mais recentemente, porém, a dogmática jurídica deu-se conta de que a subsunção tem limites, não sendo por si só suficiente para lidar com situações que, em decorrência da expansão dos princípios, são cada vez mais freqüentes. Não é difícil demonstrar e ilustrar o argumento.

Imagine-se uma hipótese em que mais de uma norma possa incidir sobre o mesmo conjunto de fatos - várias premissas maiores, portanto, para apenas uma premissa menor -, como no caso clássico da oposição entre liberdade de imprensa

30 V. Humberto ÁVILA, Teoria dos princípios (da definição à aplicação dos princípios jurídicos), cit., p. 28 e ss. O STF, no julgamento do Habeas Corpus 7703-PE (Rel. Min. Marco Aurélio, DJ 11.09.98), considerou ser essa a hipótese e afastou, no caso concreto, a aplicação do art. $1^{\circ}$ do Decreto-Lei n ${ }^{\circ}$ 200/67 para conceder a ordem e trancar ação penal proposta contra ex-Prefeita. A questão era a seguinte. Determinado Município contratou, sem concurso público, um gari por cerca de nove meses; posteriormente, o gari ingressou na justiça trabalhista exigindo um conjunto de direitos. A reclamação foi julgada improcedente pelo Juizo trabalhista, que acolheu a alegação do Município de nulidade da relação por falta de concurso público e determinou a remessa de peças ao Ministério Público para responsabilização da autoridade que dera causa ao descumprimento da regra constitucional. Com fundamento nesses fatos, o Ministério Público propôs a ação penal em face da ex-Prefeita. O STF, no entanto, considerou que o evento era insignificante, que a Municipalidade não teria sofrido prejuízo e que o fim da norma prevista no art. $1^{\circ}$ do Decreto-Lei $n^{\circ} 200 / 67$ não fora afetado e, por essas razões, determinou o trancamento da ação penal.

31 DWORKIN, Ronald. Taking rights seriously, 1997; Robert ALEXY, Teoria de los derechos fundamentales, 1997 e os seguintes textos mimeografados: Colisão e ponderação como problema fundamental da dogmática dos direitos fundamentais (1998) e Constitutional rights, balancing, and rationality (2002) (textos gentilmente cedidos por Margarida Lacombe Camargo); Karl LARENZ, Metodologia da ciência do direito, 1997; Daniel SARMENTO, A ponderação de interesses na Constituiçāo Federal, 2000; Ricardo Lobo Torres, "Da ponderação de interesses ao princípio da ponderação", in Urbano Zilles (coord.), Miguel REALE. Estudos em homenagem a seus 90 anos, 2000, p. 643 e ss: Aaron BARAK, Foreword: a judge on judging: the role of a Supreme Court in a Democracy, Harvard Law Review 116/1 (2002); Marcos Maselli GOUVÊA, O controle judicial das omissöes administrativas, 2003; Humberto ÁVILA, Teoria dos princípios (da definiçâao à aplicação dos princípios jurídicos), cit. 
e de expressão, de um lado, e os direitos à honra, à intimidade e à vida privada, de outro $^{32}$. Como se constata singelamente, as normas envolvidas tutelam valores distintos e apontam soluções diversas e contraditórias para a questão. Na sua lógica unidirecional (premissa maior - premissa menor), a solução subsuntiva para esse problema somente poderia trabalhar com uma das normas, o que importaria na escolha de uma única premissa maior, descartando-se as demais. Tal fórmula, todavia, não seria constitucionalmente adequada: por força do princípio instrumental da unidade da Constituição (v. infra), o intérprete não pode simplesmente optar por uma norma e desprezar outra em tese também aplicável, como se houvesse hierarquia entre elas. Como conseqüência, a interpretação constitucional viu-se na contingência de desenvolver técnicas capazes de lidar com o fato de que a Constituição é um documento dialético - que tutela valores e interesses potencialmente conflitantes - e que princípios nela consagrados freqüentemente entram em rota de colisão.

A dificuldade que se acaba de descrever já foi amplamente percebida pela doutrina; é pacífico que casos como esses não são resolvidos por uma subsunção simples. Será preciso um raciocínio de estrutura diversa, mais complexo, que seja capaz de trabalhar multidirecionalmente, produzindo a regra concreta que vai reger a hipótese a partir de uma síntese dos distintos elementos normativos incidentes sobre aquele conjunto de fatos. De alguma forma, cada um desses elementos deverá ser considerado na medida de sua importância e pertinência para o caso concreto, de modo que na solução final, tal qual em um quadro bem pintado, as diferentes cores possam ser percebidas, ainda que uma ou algumas delas venham a se destacar sobre as demais. Esse é, de maneira geral, o objetivo daquilo que se convencionou denominar de técnica da ponderação.

A ponderação consiste, portanto, em uma técnica de decisão jurídica ${ }^{33}$ aplicável a casos difíceis ${ }^{34}$, em relação aos quais a subsunção se mostrou insuficiente, especialmente quando uma situação concreta dá ensejo à aplicação de normas de mesma hierarquia que indicam soluções diferenciadas ${ }^{35}$. A estrutura interna do raciocínio ponderativo ainda não é bem conhecida, embora esteja sempre associada às noções difusas de balanceamento e sopesamento de interesses, bens, valores ou normas. A importância que o tema ganhou no dia a dia da atividade jurisdicional, entretanto,

32 Há diversos estudos sobre esse conflito específico. Veja-se, por todos, o trabalho de Edilsom Pereira de FARIAS, Colisão de direitos. A honra, a intimidade, a vida privada e a imagem versus a liberdade de expressão e informação, 1996.

33 SANTIAGO, José Maria Rodríguez de. La ponderación de bienes e intereses en el derecho administrativo, 2000.

34 Do inglês hard cases, a expressão identifica situações para as quais não há uma formulação simples e objetiva a ser colhida no ordenamento, sendo necessária a atuação subjetiva do intérprete e a realização de escolhas, com eventual emprego de discricionariedade.

35 A ponderação também tem sido empregada em outras circunstâncias, como na definição do conteúdo de conceitos jurídicos indeterminados (a definição dos que sejam os "valores éticos e sociais da pessoa e da família". referidos no art. 221. IV, da Constituição. envolverá por certo um raciocínio do tipo ponderativo) ou na aplicação da eqüidade a casos concretos, embora este último caso possa ser reconduzido a um confronto de princípios, já que a equididade tem como fundamento normativo específico o princípio constitucional da justiça. 
tem levado a doutrina a estudá-lo mais cuidadosamente ${ }^{36}$. De forma simplificada, é possível descrever a ponderação como um processo em três etapas, relatadas a seguir.

Na primeira etapa, cabe ao intérprete detectar no sistema as normas relevantes para a solução do caso, identificando eventuais conflitos entre elas. Como se viu, a existência dessa espécie de conflito - insuperável pela subsunção - é o ambiente próprio de trabalho da ponderaçãa ${ }^{37}$. Assinale-se que norma não se confunde com dispositivo: por vezes uma norma será o resultado da conjugação de mais de um dispositivo. Por seu turno. um dispositivo isoladamente considerado pode não conter uma norma ou, ao revés, abrigar mais de uma ${ }^{3 x}$. Ainda neste estágio, os diversos fundamentos normativos - isto é: as diversas premissas maiores pertinentes — são agrupados em função da solução que estejam sugerindo. Ou seja: aqueles que indicam a mesma solução devem formar um conjunto de argumentos. O propósito desse agrupamento é facilitar o trabalho posterior de comparação entre os elementos normativos em jogo.

Na segunda etapa, cabe examinar os fatos, as circunstâncias concretas do caso e sua interação com os elementos normativos. Relembre-se, na linha do que já foi exposto anteriormente, a importância assumida pelos fatos e pelas consequiências práticas da incidência da norma na moderna interpretação constitucional. Embora os princípios e regras tenham uma existência autônoma em tese, no mundo abstrato dos enunciados normativos, é no momento em que entram em contato com a situações concretas que seu conteúdo se preencherá de real sentido. Assim, o exame dos fatos e os reflexos sobre eles das normas identificadas na primeira fase poderão apontar com maior clareza o papel de cada uma delas e a extensão de sua influência.

Até aqui, na verdade, nada foi solucionado e nem sequer há maior novidade. Identificação das normas aplicáveis e compreensão dos fatos relevantes fazem parte de todo e qualquer processo interpretativo, sejam os casos fáceis ou difíceis. É na terceira etapa que a ponderação irá singularizar-se, em oposição à subsunção. Relembre-se, como já assentado, que os princípios, por sua estrutura e natureza. e observados determinados limites, podem ser aplicados com maior ou menor intensidade, à vista de circunstâncias jurídicas ou fáticas, sem que isso afete sua validade ${ }^{39}$. Pois bem: nessa fase dedicada à decisão, os diferentes grupos de normas e a repercussão dos fatos do caso concreto estarão sendo examinados de forma conjunta, de modo a apurar os pesos que devem ser atribuídos aos diversos elementos em disputa e, portanto, o grupo de normas que deve preponderar no caso. Em seguida, é preciso

36 TORRES. Ricardo Lobo. "Da ponderação de interesses ao princípio da ponderação". in Urbano Zilles (coord.). REALE, Miguel. Estudos em homenagem a seus 90 anos. 2000, p. 643 e ss.

37 É bem de ver que algumas vezes o conflito se estabelece mais claramente entre interesses que se opōem, quando entāo será preciso verificar se esses interesses podem ser reconduzidos a normas jurídicas (normas que, por sua vez, podem ter como fundamento regras e/ou princípios, explícitos ou implícitos).

38 Sobre o tema, v. Humberto Á vila, Teoria dos principios (da definição à aplicação dos princípios jurídicos), cit.. p. 13.

39 Essa estrutura em geral não se repete com as regras, de modo que a ponderação de regras será um fenômeno muito mais complexo e excepcional. 
ainda decidir quão intensamente esse grupo de normas - e a solução por ele indicada - deve prevalecer em detrimento dos demais. isto é: sendo possivel graduar a intensidade da solução escolhida, cabe ainda decidir qual deve ser o grau apropriado em que a solução deve ser aplicada. Todo esse processo intelectual tem como fio condutor o princípio instrumental da proporcionalidade ou razoabilidade (v. infra).

Da exposição apresentada extrai-se que a ponderação ingressou no universo da interpretação constitucional como uma necessidade, antes que como uma opção filosófica ou ideológica ${ }^{40}$. É certo, no entanto, que cada uma das três etapas descritas acima - identificação das normas pertinentes, seleção dos fatos relevantes e atribuição geral de pesos, com a produção de uma conclusão - envolve avaliações de caráter subjetivo, que poderão variar em função das circunstâncias pessoais do intérprete e de outras tantas influências ${ }^{41}$. É interessante observar que alguns dos principais temas da atualidade constitucional no Brasil tem seu equacionamento posto em termos de ponderação de valores. podendo-se destacar:

(i) o debate acerca da relativização da coisa julgada, onde se contrapõem o princípio da segurança jurídica e outros valores socialmente relevantes, como a justiça, a proteção dos direitos da personalidade e outros ${ }^{+2}$;

(ii) o debate acerca da denominada "eficácia horizontal dos direitos fundamentais", envolvendo a aplicação das normas constitucionais às relações privadas, onde se contrapõem a autonomia da vontade e a efetivação dos direitos fundamentais ${ }^{43}$;

40 Há, na verdade, quem critique essa necessidade e a própria conveniência de aplicar-se a ponderação a temas constitucionais que, por seu caráter fundamental, não deveriam estar sujeitos a avaliações tão subjetivas como as que ocorrem em um processo de ponderação: $v$. T. Alexander ALEINIKOFF. Constitutional law in the age of balancing. Yale Law Journal 96, 1987, p. 943 e ss..

41 Para o exame de algumas situações concretas de ponderação na nossa perspectiva, vejam-se em Luís Roberto BARROSO, Temas de dircito constitucional, 2002: "Liberdade de expressão, direito à informação e banimento da publicidade de cigarro", p. 243 e ss. (sobre liberdade de expressão e informação versus políticas públicas de proteção à saúde): "Liberdade de expressão, censura e controle da programação de televisão na Constituição de 1988", p. 341 e ss. (sobre liberdade de expressão versus proteção alos valores éticos e sociais da pessoa e da fumília). E em Temas de direito constitucional, ı. II, 2003: " A ordem constitucional e os limites à atuação estatal no controle de preços", p. 47 e ss. (sobre livre iniciativa e livre concorrência versus proteção do consumidor): e "Banco Central e Receita Federal. Comunicação a Ministério Público para fïs penais. Obrigatoriedade da conclusão prévia do processo administrativo". p. 539 e ss. (sobre proteção da honra imagem e privacidade versus repressão de ilícitos).

42 V. Cândido Rangel DINAMARCO, "Relativizar a coisa julgada material" in Carlos Valder do Nascimento (coord.), Coisa julgada inconstitucional, 2002, p. 33 e ss..

43 SARLET, Ingo Wolfgang. "Direitos fundamentais e direito privado: algumas considerações em torno da vinculação dos particulares aos direitos fundamentais", in Ingo Wolfgang SARLET (org.),

A Constituição concretizada. Construindo pontes com o público e o privado, 2000, p. 107 e ss. Vejam-se, também, dois projetos de doutoramento em curso perante a Pós-graduação em Direito Público da UERJ: Daniel SARMENTO. Direito humanos e relações privadas: a eficácia horizontal 
(iii)o debate acerca do papel da imprensa, liberdade de expressão e direito à informação em contraste com o direito à honra, à imagem e à vida privada.

Algumas observações finais sobre o tema. A metáfora da ponderação, associada ao próprio símbolo da justiça, não é imune a críticas, sujeita-se ao mau uso e não é remédio para todas as situações. Embora tenha merecido ênfase recente, por força da teoria dos princípios, trata-se de uma idéia que vem de longe ${ }^{44}$. Há quem a situe como um componente do princípio mais abrangente da proporcionalidade ${ }^{45}$ e outros que já a vislumbram como um princípio próprio, autônomo, o princípio da ponderação ${ }^{46}$. É bem de ver, no entanto, que a ponderação, embora preveja a atribuição de pesos diversos aos fatores relevantes de uma determinada situação, não fornece referências materiais ou axiológicas para a valoração a ser feita. No seu limite máximo, presta-se ao papel de oferecer um rótulo para voluntarismos e soluções ad hoc, tanto as bem-inspiradas como as nem tanto ${ }^{47}$.

O risco de tal disfunção, todavia, não a desmerece como técnica de decisão nem priva a doutrina da possibilidade de buscar parâmetros melhor definidos para sua aplicação. No estágio atual, a ponderação ainda não atingiu o padrão desejável de objetividade, dando lugar a ampla discricionariedade judicial. Tal discricionariedade, no entanto, como regra, deverá ficar limitada às hipóteses em que o sistema jurídico não tenha sido capaz de oferecer a solução em tese, elegendo um valor ou interesse que deva prevalecer. A existência de ponderação não é um convite para o exercício indiscriminado de ativismo judicial. O controle de legitimidade das decisões obtidas mediante ponderação tem sido feito através do exame da argumentação desenvolvida. Seu objetivo, de forma bastante simples, é verificar a correção dos argumentos apresentados em suporte de uma determinada conclusão ou ao menos a racionalidade do raciocínio desenvolvido em cada caso, especialmente quando se trate do emprego da ponderação. O próximo tópico será dedicado a esse tema.

dos direitos fundamentais na Constituição brasileira, 2002, e Jane Reis Gonçalves PEREIRA, $O$ sistema de interpretação dos direitos fundamentais, 2002.

44 POUND, Roscoe. Interpretarions of legal history, 1923 é citado como grande impulsionador da moderna técnica de ponderação, no âmbito da "jurisprudência sociológica". V. Murphy, FLEMING e HARRIS, II. American constitutional interpretation, 1986, p. 309.

45 ALEXY, Robert. Constitutional rights, balancing, and rationality, 2002, mimeografado, p. 6. 46 Ricardo Lobo Torres, "Da ponderação de interesses ao princípio da ponderação", in Urbano Zilles (coord.), REALE, Miguel. Estudos em homenagem a seus 90 anos, 2000, p. 643 e ss.

47 SILVA, Antônio Henrique Corrêa da. em monografia de final de curso na Pós-graduação em Direito Público da UERJ, signiticativamente denominada de Colisão de princípios e ponderaçāo de interesses: soluçāo ruim para problema inexistente, 2002, faz densa crítica à idéia de ponderação em si e, considerando artificiais as distinções entre regra e princípio, concluiu: "a) a distinção entre regra e princípio é inócua do ponto de vista funcional, uma vez que o princípio não pode operar por si só, mas apenas através de uma regra que dele se extraia; b) a 'colisão de princípios' é, na verdade, um conflito de regras extraídas de princípios, que podem ou nāo ser solucionáveis (rectius: solucionável) pelos critérios tradicionais de superação de antinomias." 


\section{A teoria da argumentação ${ }^{48}$}

Após um primeiro momento de perplexidade, os iniciantes no estudo do Direito passam a encarar com naturalidade um fenômeno que causa estranheza a uma pessoa leiga: a existência de decisões em sentidos opostos acerca de uma mesma matéria, posições doutrinárias divergentes e até mesmo votos conflitantes em um mesmo julgado ${ }^{49}$. Isto é: considerados os mesmos fatos e os mesmos elementos normativos, pessoas diferentes poderão chegar a conclusōes diversas. A principal questão formulada pela chamada teoria da argumentação ${ }^{50}$ pode ser facilmente visualizada nesse ambiente: se há diversas possibilidades interpretativas acerca de uma mesma hipótese, qual delas é a correta? Ou, mais humildemente, ainda que não se possa falar de uma decisão correta ${ }^{51}$, qual (ou quais) delas é (são) capaz(es) de apresentar uma fundamentação racional consistente? Como verificar se uma determinada argumentação é melhor do que outra?

Existem diversas teorias acerca dos parâmetros que a argumentação deve observar para ser considerada válida e não se pretende aqui discutir suas complexidades, cujo exame forma por si só um ramo novo e autônomo de estudo ${ }^{52}$. Mesmo sem ingressar nelas, no entanto, é possível sistematizar três parâmetros elementares de

48 Sobre o tema, v. Chaim PERELMAN e Lucie OLBRECHTS-TYTECA, Tratado da argumentação: a nova retórica, 1996 ( $1^{4}$. edição do original Traité de l'argumentation: la nouvelle rhétorique, 1958); Stephen E. TOULMIN, The uses of argument, 1958; Neil MACCORMICK, Legal reasoning and legal theory, 1978; Robert Alexy, Teoria de la argumentación jurídica, 1989 ( $\left(1^{2}\right.$. edição do original Theorie der juristischen Argumentation, 1978); Manuel ATIENZA, As razões do direito. Teorias da argumentação jurídica, 2002; Antônio Carlos Cavalcanti Maia, "Notas sobre direito, argumentaçāo e democracia", in Margarida Maria Lacombe CAMARGO (org.), 1988-1998: uma década de Constituição, 1999.

49 O HC 73662/MG (STF, Rel. Min. Marco Aurélio, DJ 20.09.96) é um exemplo interessante e emblemático do que se afirma. A discussão envolvia a interpretação dos arts. 213 e 224, alínea "a", do Código Penal, e em particular da presunção de violência nos casos de relação sexual com menor de 14 anos, para o fim de tipificar-se o crime de estupro. O voto do Relator defendeu que a presunção deveria ser compreendida como relativa, tanto pelas circunstâncias do caso concreto (a menor levava vida promíscua, aparentava maior idade e consentiu com a relação sexual), como por força da norma constitucional que prevê deva ser conferida especial proteção à família (art. 226). Isso porque, segundo o Ministro Relator, 5 (cinco) anos já se haviam passado do evento e, nesse ínterim, o paciente no habeas corpus, condenado por estupro, havia casado e constituído família. Os votos vencidos, por outro lado, e afora outros argumentos, defendiam a presunção absoluta de violência no caso com fundamento no art. 227 . $\$ 4^{\circ}$, da Constituição, pelo qual "a lei punirá severamente o abuso, a violência e a exploração sexual da criança e do adolescente".

$50 \mathrm{Na}$ verdade, há várias teorias sobre a argumentação, mas suas preocupações concentram-se em elementos comuns, de modo que se estará fazendo referência a elas de forma unificada.

5ı Com efeito, praticamente todas as teorias que se têm desenvolvido acerca dos parâmetros que a argumentação deve observar para ser considerada válida reconhecem que, muitas vezes, não haverá uma resposta certa, mas um conjunto de soluções plausíveis e razoáveis. V. Manuel Atienza, As razōes do direito. Teorias da argumentação jurídica, 2002, p. 40 e ss.

52 ATIENZA, Manuel. em As razōes do direito. Teorias da argumentação jurídica, 2002, faz uma apresentação do pensamento dos principais autores sobre o assunto. 
controle da argumentação que, a despeito de sua simplicidade, serão especialmente úteis quando a técnica da ponderação esteja sendo utilizada.

Em primeiro lugar, a argumentação jurídica deve ser capaz de apresentar fundamentos normativos (implícitos que sejam) que a apóiem e lhe dêem sustentação. Ou seja: não basta o bom senso e o sentido de justiça pessoal - é necessário que o intérprete apresente elementos da ordem jurídica que referendem tal ou qual decisão. Embora óbvia, essa exigência tem sido deixada de lado com mais frequiência do que se poderia supor, substituída por concepções pessoais embaladas em uma retórica de qualidade. Não custa lembrar que, em um Estado democrático de direito, o Judiciário apenas pode impor coativamente determinada conduta a alguém com fundamento em lei. A argumentação jurídica deve preservar exatamente seu caráter jurídico — não se trata apenas de uma argumentação lógica ou moral. Nessa mesma linha, ao menos como orientação prima facie, um conflito normativo deve ser resolvido em favor da solução que apresente em seu suporte o maior número de normas jurídicas ${ }^{53}$. Nesse ponto, é oportuno fazer uma observação de caráter geral.

Apenas será possível controlar a argumentação do intérprete se houver uma argumentação explicitamente apresentada. Essa evidência conduz ao problema da motivação das decisões que envolvam a técnica da ponderação, particularmente as decisões judiciais. Como é corrente, toda e qualquer decisão judicial deve ser motivada quanto aos fatos e quanto ao direito; mas quando uma decisão judicial envolve a técnica da ponderação, o dever de motivar torna-se ainda mais grave. Nesses casos, como visto, o julgador percorre um caminho muito mais longo e acidentado para chegar à conclusão É seu dever constitucional guiar as partes por essa viagem, demonstrando, em cada ponto, porque decidiu por uma direção ou sentido e não por outro.

Nada obstante o truísmo do que se acaba de afirmar, provavelmente nunca se motivou tão pouco e tão mal ${ }^{54}$. Há uma série de explicações para esse fenômeno, que vão do excesso de trabalho atribuído aos juízes, passam pela chamada "motivação concisa", autorizada pela jurisprudência das Cortes superiores ${ }^{55}$, e pelas recentes reformas do Código de Processo Civil, que admite agora como fundamen-

53 ÁVILA, Humberto. Argumentação jurídica e a imunidade do livro eletrônico, Revista de Direito Tributário $79 / 178$ e ss..

54 A ausência de motivação chega, às vezes, a ser tautológica, como registrou o Ministro Sepúlveda Pertence no acórdão que segue: "Sentença condenatória: o acórdão que improvê apelação: motivação necessária. A apelaçãa devolve integralmente ao Tribunal a decisão da causa, de cujos motivos o teor do acórdão há de dar conta total: não o faz o que - sem sequer transcrever a sentença limita-se a afirmar, para refutar apelação arrazoada com minúcia, que 'no mérito, não tem os apelantes qualquer parcela de razão'. somando-se ao vazio dessa afirmação a tautologia de que 'a prova é tranquiila em desfavor dos réus': a melhor prova da ausência de motivação válida de uma decisão judicial - que deve ser a demonstração da adequação do dispositivo a um caso concreto e singular - é que ela sirva a qualquer julgado, o que vale por dizer que não serve a nenhum." (STF, HC 78013/RJ, DJ 19.03.99. Rel. Min. Sepúlveda Pertence).

55 STF, AI(AgR) 310272-RJ, DJ 28.06.02. Rel. Min. Maurício Corrêa: "A fundamentação concisa atende à exigência do artigo 93, IX da Constituição Federal, não implicando a invalidação da decisão que a utiliza." 
tação de determinadas decisões a mera referência a súmulas ${ }^{56}$. Não é o momento aqui de examinar cada uma dessas questões. Ainda que se possam admitir motivaçóes concisas em muitos casos, certamente isso não é possível quando se trate de decidir adotando a técnica de ponderação. Nessas hipóteses, é absolutamente indispensável que o julgador exponha analítica e expressamente o raciocínio e a argumentação que o conduziram a uma determinada conclusão, permitindo assim que as partes possam controlá-la.

Feita a digressão, e retornando ao ponto, um segundo parâmetro útil para o controle da argumentação jurídica, em especial quando ela envolva a ponderação, diz respeito à possibilidade de universalização dos critérios adotados pela decisão. Por força do imperativo de isonomia, espera-se que os critérios empregados para a solução de um determinado caso concreto possam ser transformados em regra geral para situações semelhantes. Esse exercício de raciocínio - verificar a possibilidade de generalizar o critério de decisão que se pretende adotar no caso concreto - projeta a argumentação desenvolvida para o caso concreto em um conjunto maior de hipóteses, facilitando a visualização de desvios e inconsistências.

Por fim, um último parâmetro capaz de balizar de alguma forma a argumentação jurídica, especialmente a constitucional, é formado por dois conjuntos de princípios: o primeiro, composto de princípios instrumentais ou específicos de interpretação constitucional; o segundo, por princípios materiais propriamente ditos, que trazem em si a carga ideológica, axiológica e finalística da ordem constitucional. Ambas as categorias de princípios orientam a atividade do intérprete, de tal maneira que, diante de várias soluçōes igualmente plausíveis, deverá ele percorrer o caminho ditado pelos princípios instrumentais e realizar, tão intensamente quanto possível, à luz dos outros elementos em questão, o estado ideal pretendido pelos princípios materiais.

Aqui vale fazer uma nota. Os três parâmetros de argumentação expostos acima estão relacionados com $u m$ dos problemas suscitados pela teoria da argumentação, talvez o principal deles: a verificação da correção ou validade de uma argumentação que, consideradas determinadas premissas fáticas e a incidência de determinadas normas, conclui que uma conseqüência jurídica deve ser aplicada ao caso concreto. Isto é: cuida-se aqui do momento final da aplicação do direito, quando os fatos já foram identificados e as normas pertinentes selecionadas. Isso não significa, porém, que esses dois momentos anteriores - seleção de fatos e de enunciados normativos - sejam auto-evidentes. Ao contrário.

Desse modo, fica apenas o registro de que, além da questão posta acima, outros dois problemas que têm ocupado os estudiosos da argumentação jurídica envolvem exatamente a seleção das normas e dos fatos que serão considerados em uma

$56 \mathrm{CPC}$, art. 557: "O relator negará seguimento a recurso manifestamente inadmissível, improcedente, prejudicado ou em confronto com súmula ou com jurisprudência dominante do respectivo Tribunal, do Supremo Tribunal Federal, ou de Tribunal Superior.

$\$ 1^{\circ}$ - A Se a decisão recorrida estiver em manifesto confronto com súmula ou com jurisprudência dominante do Supremo Tribunal Federal, ou de Tribunal Superior, o relator poderá dar provimento ao recurso". 
determinada situação. Com efeito, não é incomum, diante de um caso, que alguns fatos sejam considerados relevantes e outros ignorados. Que critérios levam o intérprete a dar relevância jurídica a alguns eventos e ignorar outros ${ }^{57}$ ? Também a seleção da norma ou normas aplicáveis, isto é, o estabelecimento da premissa normativa, nem sempre é um evento simples. A pergunta aqui, que muitas vezes não terá uma resposta unívoca, pode ser formulada nos seguintes termos: que normas são pertinentes ou aplicáveis ao caso ${ }^{58}$ ?

Em suma, o controle da racionalidade do discurso jurídico suscita questões diversas e complexas, que se tornam tanto mais graves quanto maior seja a liberdade concedida a quem interpreta. No caso da interpretação constitucional, a argumentação assume, muitas vezes, um papel decisivo: é que o caráter aberto de muitas normas, o espaço de indefinição de conduta deixado pelos princípios e os conceitos indeterminados conferem ao intérprete elevado grau de subjetividade. A demonstração lógica adequada do raciocínio desenvolvido é vital para a legitimidade da decisão proferida $^{59}$.

57 Um exemplo dessa espécie de problema pode ser observado na decisão do Supremo Tribunal Federal que considerou legítima a aplicação de aumento da alíquota do imposto de renda, publicado ao longo de determinado ano, ao fato gerador que se consolidou em 31 de dezembro daquele mesmo ano. Na hipótese. era possível considerar ao menos dois fatos aparentemente relevantes: (i) o fato gerador já estava em curso quando do incremento da alíquota; e (ii) o fato gerador se consolida no dia 31 de dezembro. $O$ intérprete que tomasse em consideração apenas o primeiro fato poderia concluir pela inconstitucionalidade do aumento, tendo em conta o princípio constitucional da anterioridade tributária. Por outro lado, aquele que apenas considerasse relevante o segundo, como fez o STF, entenderia constitucional a incidência do aumento desde logo. Confira-se: "Tratava-se, nesse precedente, como nos da súmula, de Lei editada no final do ano-base, que atingiu a renda apurada durante todo o ano, já que o fato gerador somente se completa e se caracteriza, ao final do respectivo período, ou seja, a 31 de dezembro" (STF, RE 194.612-1, DJ 08.05.98, Rel. Min. Sydney Sanches).

58 Nos casos, e.g., em que o conteúdo de matérias jornalísticas se pode opor à honra e à privacidade, há autores que procuram solucionar o problema afirmando que a liberdade de expressão assegurada constitucionalmente é aplicável apenas às pessoas naturais, individualmente consideradas, e não às empresas que exploram meios de comunicação. Estas gozariam apenas da liberdade de empresa e de iniciativa, direitos também assegurados pela Constituição, mas que poderiam ser restringidos com muito maior facilidade que a liberdade de expressão, prevista, afinal, como uma cláusula pétrea. Esta é a posição do professor Fábio Konder COMPARATO, expressa em obra coletiva em homenagem a Paulo BONAVIDES ("A democratização dos meios de comunicação de massa", in Eros Roberto GRAU e Willis Santiago GUERRA FILHO, Direito constitucional. Estudos em homenagem ao Paulo Bonavides, 2001). Ora, o fato de a liberdade de expressão ser ou não um elemento normativo relevante no caso é fundamental para sua solução.

59 Comentando a absolvição do ex-presidente Collor em artigo publicado no Jornal do Brasil ( $O$ avesso do Direito) e reproduzido parcialmente na Revista Consulex v. I, n 19, 1998 (Juristas analisam a candidatura Collor), escreveu Luís Roberto Barroso: “A decisão do STF que absolveu o ex-Presidente Fernando Collor comporta mais de uma leitura. É possível alguém supor, em boa fé, que os cinco ministros que consideraram o Presidente inocente simplesmente não se convenceram de sua culpabilidade. Provavelmente, além de Suas Excelências, dos advogados de defesa e da estranha gente que recebe a alcunha de 'tropa de choque', não teria sido possível contabilizar outras cinco pessoas no País inteiro que pensassem igual. (...) Mas há outra leitura possível da decisão 
Em desfecho desta parte do trabalho, faz-se a seguir, para ilustrar as idéias desenvolvidas, um exercício singelo de ponderação e argumentação. Suponha-se o seguinte fato: o ocupante de um importante cargo político na República é visto na saída de um motel, acompanhado de uma senhora que não é sua esposa. Um jornalista que se encontrava na calçada em frente fotografa o casal, ainda sob a placa identificadora do estabelecimento. A foto irá ilustrar a capa de uma importante revista semanal, que circulará no sábado seguinte, trazendo ampla matéria intitulada "A infidelidade no poder". Tomando conhecimento do fato, a autoridade propõe medida judicial de natureza cautelar com o fim de impedir a publicação de sua foto e de referências à sua pessoa, invocando seu direito de privacidade (CF, art. $5, \mathrm{X})$ e alegando que: estava em seu carro particular, fora do horário do expediente e que não há qualquer interesse legítimo em divulgar fatos de sua vida pessoal e sexual. Os direitos contrapostos, como intuitivo, são os da liberdade de expressão (CF, art. 5, IX) e o da informação (CF, arts. 5, XIV, e 220).

Não é um caso fácil, por envolver um conflito entre direitos fundamentais, sem que o ordenamento jurídico forneça, em tese, a solução constitucionalmente adequada. O juiz, portanto, terá de fazer a ponderação entre os valores em conflito e efetuar escolhas. E, reconheça-se, pessoas esclarecidas e de boa fé poderão produzir soluções diferentes para o problema. Veja-se a demonstração argumentativa de uma delas. Apreciando a matéria, o juiz de primeiro grau nega a liminar, fundamentando sua decisão em um teste tríplice:

a) $O$ fato é verdadeiro. Argumento: somente em situações de rara excepcionalidade deve o Judiciário impedir, mediante interferência prévia, a divulgação de um fato que incontroversamente ocorreu;

b) $O$ conhecimento do fato foi obtido por meio lícito. Argumento: O Judiciário pode e deve interferir para impedir a divulgação de uma notícia se ela tiver sido produto, por exemplo, de um crime, como uma interceptação telefônica clandestina ou uma invasão de domicílio. Não sendo este o caso, não deve fazê-lo;

c) Há interesse público potencial no conhecimento do fato. Suponha-se que a autoridade em questão exercesse seu cargo no Ministério dos Transportes, onde uma importante licitação estivesse por ser decidida. E que a senhora

majoritária do STF. A teoria convencional do Direito sustenta que o juiz é um mero aplicador da lei. Seu papel consiste tão-somente em apurar os fatos e sobre eles fazer incidir o comando da norma. Mecanicamente. Acriticamente. Vive-se a ficção implausível de que o Estado é inteiramente neutro e seus agentes são totalmente imparciais. O terceiro-mundismo tem dessas hipocrisias. $\mathrm{Na}$ verdade, por um processo que é frequentemente inconsciente, o que se constata é que por trás do discurso aparentemente jurídico o que existe é o compromisso ideológico, o sentimento de classe. Os afortunados e os não afortunados. O que acontece no dia-a-dia da Justiça se materializou de forma emblemática na decisão do Supremo: a classe dominante brasileira - e seus intérpretes conscientes e inconscientes nos tribunais - não consegue condenar os seus pares, os seus iguais." 
que o acompanhava estivesse a serviço de um dos licitantes, utilizando argumentos - como dizer — não previstos no edital.

Em sua fundamentação, portanto, o juiz levou em conta as normas constitucionais relevantes, os elementos do caso concreto e a existência ou não de interesse público legitimador de uma determinada opção. Esta solução não era a única possível, pois o domínio dos conflitos de direitos fundamentais não é de verdades ou certezas absolutas. Mas a argumentação desenvolvida é suficientemente lógica e racional para pretender conquistar a adesão de um universo de pessoas bem intencionadas e esclarecidas.

\section{PARTE II ${ }^{60}$ \\ PRINCÍPIOS CONSTITUCIONAIS}

\section{Princípios instrumentais de interpretação constitucional}

As normas constitucionais são normas jurídicas e, como conseqüência, sua interpretação serve-se dos conceitos e elementos clássicos da interpretação em geral. Todavia, as normas constitucionais apresentam determinadas especificidades que as singularizam, dentre as quais é possível destacar: a) a superioridade jurídica ${ }^{61}$; b) a natureza da linguagem ${ }^{62}$; c) o conteúdo específico ${ }^{63}$; d) o caráter político ${ }^{64}$. Em razão

60 A Parte II do presente texto sintetiza e consolida idéias expostas em Luís Roberto BARROSO, Interpretação e aplicação da Constituição, 2003 e Ana Paula de BARCELLOS, A eficácia jurídicas dos princípios constitucionais. O princípio da dignidade da pessoa humana, 2001.

61 A Constituição é dotada de superlegalidade, de superioridade jurídica em relação às demais normas do ordenamento. Tal característica faz dela o parâmetro de validade, o paradigma pelo qual se afere a cornpatibilidade de uma norma com o sistema como um todo. Adiante se voltará ao tema. 62 A natureza da linguagem constitucional, própria à veiculação de normas principiológicas ou esquemáticas, faz com que estas apresentem maior abertura, maior grau de abstração e, conseqüentemente, menor densidade jurídica. Cláusulas gerais e conceitos indeterminados conferem à Constituição uma adaptabilidade às mudanças operadas na realidade e ao intérprete um significativo espaço de discricionariedade.

63 As normas materialmente constitucionais podem ser classificadas em três grandes categorias: a) as normas constitucionais de organização, que contêm as decisões políticas fundamentais, instituem os órgãos de poder e definem suas competências; b) as normas constitucionais definidoras de direitos, que identificam os direitos individuais, políticos, sociais e coletivos de base constitucional; e c) as normas programáticas, que estabelecem valores e fins públicos a serem realizados. As normas definidoras de direitos têm, como regra, a estrutura típica das normas de conduta, presentes nos diferentes ramos do Direito: prevêem um fato e a ele atribuem uma consequiência jurídica. Mas as normas de organização e as normas programáticas têm características singulares na sua estrutura e no seu modo de aplicação.

64 A Constituição é o documento que faz a travessia entre o poder constituinte originário - fato político - e a ordem instituída, que é um fenômeno jurídico. Cabe ao direito constitucional o 
disso, desenvolveram-se ou sistematizaram-se categorias doutrinárias próprias, identificadas como princípios específicos ou princípios instrumentais de interpretação constitucional.

Impõe-se, nesse passo, uma qualificação prévia. O emprego do termo princípio, nesse contexto, prende-se à proeminência e à precedência desses mandamentos dirigidos ao intérprete, e não propriamente ao seu conteúdo, à sua estrutura ou à sua aplicação mediante ponderação. Os princípios instrumentais de interpretação constitucional constituem premissas conceituais, metodológicas ou finalísticas que devem anteceder, no processo intelectual do intérprete, a solução concreta da questão posta. Nenhum deles encontra-se expresso no texto da Constituição, mas são reconhecidos pacificamente pela doutrina e pela jurisprudência. Embora toda classificação tenha um componente subjetivo, a sistematização que se segue parece ter resistido ao teste do tempo ${ }^{65}$.

\section{I.1. Princípio da supremacia da Constituição}

Do ponto de vista jurídico, o principal traço distintivo da Constituição é a sua supremacia, sua posição hierárquica superior à das demais normas do sistema. As leis, atos normativos e atos jurídicos em geral não poderão existir validamente se incompatíveis com alguma norma constitucional. A Constituição regula tanto o modo de produção das demais normas jurídicas como também delimita o conteúdo que possam ter. Como consequiência, a inconstitucionalidade de uma lei ou ato normativo poderá ter caráter formal ou material. A supremacia da Constituição é assegurada pelos diferentes mecanismos de controle de constitucionalidade. O princípio não tem um conteúdo próprio: ele apenas impõe a prevalência da norma constitucional, qualquer que seja ela. É por força da supremacia da Constituição que o intérprete pode deixar de aplicar uma norma inconstitucional a um caso concreto que the caiba apreciar - controle incidental de constitucionalidade - ou o Supremo Tribunal

enquadramento jurídico dos fatos políticos. Embora a interpretação constitucional não possa e não deva romper as suas amarras jurídicas, deve ela ser sensível à convivência harmônica entre os Poderes, aos efeitos simbólicos dos pronunciamentos do Supremo Tribunal Federal e aos limites e possibilidades da atuação judicial.

65 Esta foi a ordenação da matéria proposta em nosso Interpretação e aplicação da Constituição, cuja $1^{a}$. edição é de 1995 . Autores alemães e portugueses de grande expressão adotam sistematizaçōes diferentes, mas o elenco acima parece o de maior utilidade, dentro de uma perspectiva brasileira de concretização da Constituição. Na doutrina brasileira mais recente, embora de forte influência germânica, destaca-se o tratamento dado ao tema por Humberto ÁVILA, em seu Teoria dos princípios (da definição à aplicação dos princípios jurídicos), cit. Propõe ele a superação do modelo dual de separação regras-princípios pela criação de uma terceira categoria normativa: a dos postulados normativos aplicativos. Seriam eles "instrumentos normativos metódicos" que imporiam "condições a serem observadas na aplicação das regras e dos princípios, com eles não se confundindo". Em alguma medida, tal categoria se aproxima daquilo que temos denominado de princípios instrumentais de interpretação constitucional. Todavia, sua classificação é bem distinta, nela se identificando o que denomina de postulados inespecíficos (ponderação, concordância prática e proibição de excesso) e postulados específicos (igualdade, razoabilidade e proporcionalidade). 
Federal pode paralisar a eficácia, com caráter erga omnes, de uma norma incompatível com o sistema constitucional (controle principal ou por ação direta).

\section{I.2. Princípio da presunção de constitucionalidade das leis e atos do poder público}

A Constituição contém o código de conduta dos três Poderes do Estado, cabendo a cada um deles sua interpretação e aplicação no âmbito de sua competência. De fato, a atividade legislativa destina-se, em última análise, a assegurar os valores e a promover os fins constitucionais. A atividade administrativa, tanto normativa quanto concretizadora, igualmente se subordina à Constituição e destina-se a efetivá-la. $O$ Poder Judiciário, portanto, não é o único intérprete da Lei Maior, embora o sistema lhe reserve a primazia de dar a palavra final. Por isso mesmo, deve ter uma atitude de deferência para com a interpretação levada a efeito pelos outros dois ramos do governo, em nome da independência e harmonia dos Poderes. O princípio da presunção de constitucionalidade, portanto, funciona como fator de autolimitação da atuação judicial: um ato normativo somente deverá ser declarado inconstitucional quando a invalidade for patente e não for possível decidir a lide com base em outro fundamento.

\section{I.3. Princípio da interpretação conforme a Constituição}

A interpretação conforme a Constituição pode ser apreciada como um princípio de interpretação e como uma técnica de controle de constitucionalidade. Como princípio de interpretação, decorre ele da confluência dos dois princípios anteriores: o da supremacia da Constituição e o da presunção de constitucionalidade. Com base na interpretação conforme a Constituição, o aplicador da norma infraconstitucional, dentre mais de uma interpretação possível, deverá buscar aquela que a compatibilize com a Constituição, ainda que não seja a que mais obviamente decorra do seu texto. Como técnica de controle de constitucionalidade, a interpretação conforme a Constituição consiste na expressa exclusão de uma determinada interpretação da norma, uma ação "corretiva" que importa em declaração de inconstitucionalidade sem redução de texto. Em qualquer de suas aplicações, o princípio tem por limite as possibilidades semânticas do texto, para que o intérprete não se converta indevidamente em um legislador positivo.

\section{I.4. Princípio da unidade da Constituição}

A ordem jurídica é um sistema, o que pressupõe unidade, equilíbrio e harmonia. Em um sistema, suas diversas partes devem conviver sem confrontos inarredáveis. Para solucionar eventuais conflitos entre normas jurídicas infraconstitucionais utilizam-se, como já visto, os critérios tradicionais da hierarquia, da norma posterior e o da especialização. Na colisão de normas constitucionais, especialmente de princípios - mas também, eventualmente, entre princípios e regras e entre regras e regras - emprega-se a técnica da ponderação. Por força do princípio da unidade, inexiste 
hierarquia entre normas da Constituição, cabendo ao intérprete a busca da harmonização possível, in concreto, entre comandos que tutelam valores ou interesses que se contraponham. Conceitos como os de ponderação e concordância prática são instrumentos de preservação do princípio da unidade, também conhecido como princípio da unidade hierárquico-normativa da Constituição.

\subsection{Princípio da razoabilidade ou da proporcionalidade ${ }^{66}$}

O princípio da razoabilidade ou da proporcionalidade, termos aqui empregados de modo fungível ${ }^{67}$, não está expresso na Constituição, mas tem seu fundamento nas idéias de devido processo legal substantivo e na de justiça. Trata-se de um valioso instrumento de proteção dos direitos fundamentais e do interesse público, por permitir o controle da discricionariedade dos atos do Poder Público e por funcionar como a medida com que uma norma deve ser interpretada no caso concreto para a melhor realização do fim constitucional nela embutido ou decorrente do sistema. Em resumo sumário, o princípio da razoabilidade permite ao Judiciário invalidar atos legislativos ou administrativos quando: a) não haja adequação entre o fim perseguido e o instrumento empregado (adequação); b) a medida não seja exigível ou necessária, havendo meio alternativo menos gravoso para chegar ao mesmo resultado (necessidade/vedaçāo do excesso); c) não haja proporcionalidade em sen-

66 Sobre o tema, v. Luís Roberto BARROSO, Interpretação e aplicação da Constituição, 2002, p. 213 e ss., onde se faz amplo levantamento da bibliografia na matéria.

67 A idéia de razoabilidade remonta ao sistema jurídico anglo-saxão, tendo especial destaque no direito norte-americano, como desdobramento do conceito de devido processo legal substantivo. $O$ princípio foi desenvolvido, como próprio do sistema do common law, através de precedentes sucessivos, sem maior preocupação com uma formulação doutrinária sistemática. Já a noção de proporcionalidade vem associada ao sistema jurídico alemão, cujas raízes romano-germânicas conduziram a um desenvolvimento dogmático mais analítico e ordenado. De parte isto, deve-se registrar que o princípio, nos Estados Unidos, foi antes de tudo um instrumento de direito constitucional, funcionando como um critério de aferição da constitucionalidade de determinadas leis. Já na Alemanha, o conceito evoluiu a partir do direito administrativo, como mecanismo de controle dos atos do Executivo. Sem embargo da origem e do desenvolvimento diversos, um e outro abrigam os mesmos valores subjacentes: racionalidade, justiça, medida adequada, senso comum, rejeição aos atos arbitrários ou caprichosos. Por essa razão, razoabilidade e proporcionalidade são conceitos próximos o suficiente para serem intercambiáveis. Este é o ponto de vista que tenho sustentado desde a $1^{\mathbf{a}}$. edição de meu Interpretação e aplicação da Constituição, que é de 1995 . No sentido do texto, v. por todos Fábio Corrêa Souza de OLIVEIRA, Por uma teoria dos principios. O princípio constitucional da razoabilidade, 2003, p. 81 e ss.

É certo, no entanto, que a linguagem é uma convenção. E se nada impede que se atribuam significados diversos à mesma palavra, com muito mais razão será possível fazê-lo em relação a vocábulos distintos. Basta, para tanto, qualificar previamente a acepção com que se está empregando um determinado termo. É o que faz, por exemplo, Humberto ÁVILA (Teoria dos princípios, cit.), que explicita conceitos diversos para proporcionalidade e razoabilidade. Ainda na mesma temática, Luís Virgílio Afonso da SILVA (O proporcional e o razoável, RT 798/23) investe grande energia procurando demonstrar que os termos não são sinônimos e critica severamente a jurisprudência do STF na matéria. 
tido estrito, ou seja, o que se perde com a medida é de maior relevo do que aquilo que se ganha (proporcionalidade em sentido estrito). O princípio pode operar, também, no sentido de permitir que o juiz gradue o peso da norma, em uma determinada incidência, de modo a não permitir que ela produza um resultado indesejado pelo sistema, assim fazendo a justiça do caso concreto.

\subsection{Principio da eferividade}

Consoante doutrina clássica, os atos jurídicos em geral, inclusive as normas jurídicas, comportam análise em três planos distintos: os da sua existência, validade e efícácia. No período imediatamente anterior e ao longo da vigência da Constituição de 1988, consolidou-se um quarto plano fundamental de apreciação das normas constitucionais: o da sua efetividade. Efetividade significa a realização do Direito, a atuação prática da norma, fazendo prevalecer no mundo dos fatos os valores e interesses por ela tutelados. Simboliza a efetividade, portanto, a aproximação, tão íntima quanto possível, entre o dever ser normativo e o ser da realidade social ${ }^{68}$. O intérprete constitucional deve ter compromisso com a efetividade da Constituição: entre interpretações alternativas e plausíveis, deverá prestigiar aquela que permita a atuação da vontade constitucional, evitando, no limite do possível, soluções que se refugiem no argumento da não auto-aplicabilidade da norma ou na ocorrência de omissão do legislador.

\section{Os princípios constitucionais materiais: uma classificação}

Uma classificação que tem se mostrado útil e parece ter resistido ao teste do tempo é a que procura singularizar os princípios - princípios materiais, note-se, e não mais instrumentais - de acordo com o seu destaque no âmbito do sistema e a sua abrangência ${ }^{69}$. Os princípios, ao expressar valores ou indicar fins a serem alcançados pelo Estado e pela sociedade, irradiam-se pelo sistema, interagem entre si e pautam a atuação dos órgãos de poder, inclusive a do Judiciário na determinação do sentido das normas. Nem todos os princípios, todavia, possuem o mesmo raio de ação. Eles variam na amplitude de seus efeitos e mesmo no seu grau de influência. Por essa razão, podem ser agrupados em três categorias diversas, que identificam os princípios como fundamentais, gerais e setoriais.

\section{II.1. Principios fundamentais}

Os princípios fundamentais expressam as principais decisões políticas no âmbito do Estado, aquelas que vão determinar sua estrutura essencial. Veiculam, assim, a forma, o regime e o sistema de governo, bem como a forma de Estado. De tais opções

68 BARROSO. Luís Roberto. O direito constitucional e a efetividade de suas normas, 2002. 69 BARROSO, Luís Roberto. Princípios constitucionais brasileiros (ou de como o papel aceita tudo), RTDP $1 / 168$. 
resultará a configuração básica da organização do poder político ${ }^{70}$. Também se incluem nessa categoria os objetivos indicados pela Constituição como fundamentais à República ${ }^{71}$ e os princípios que a regem em suas relações internacionais ${ }^{72}$. Por fim, merece destaque em todas as relações públicas e privadas o princípio da dignidade da pessoa humana (art. 1, III), que se tornou o centro axiológico da concepção de Estado democrático de direito e de uma ordem mundial idealmente pautada pelos direitos fundamentais.

\section{II.2. Principios gerais}

Os princípios constitucionais gerais, embora não integrem o núcleo das decisões políticas que conformam o Estado, são importantes especificações dos princípios fundamentais. Têm eles menor grau de abstração, sendo mais facilmente determinável o núcleo em que operam como regras. Por tal razão, prestam-se de modo corrente à tutela direta e imediata das situações jurídicas que contemplam. Por serem desdobramentos dos princípios fundamentais, irradiam-se eles por toda a ordem jurídica ${ }^{73}$. A maior parte dos princípios gerais concentra-se no art. 5 da Constituição, dedicado aos direitos e deveres individuais e coletivos, o que apenas ratifica a equiparação doutrinária que se costuma fazer entre direitos fundamentais e princípios ${ }^{74}$.

\section{II.3. Principios setoriais}

Princípios setoriais ou especiais são aqueles que presidem um específico conjunto de normas afetas a determinado tema, capítulo ou título da Constituição. Eles

70 E.g., princípio republicano (art. $1^{\circ}$, caput), princípio federativo (art. $1^{\circ}$, caput), princípio do Estado democrático de direito (art. $1^{\circ}$, caput), princípio da separação de Poderes (art. $2^{\circ}$ ), princípio presidencialista (art. 76), princípio da livre iniciativa (art. $1^{\circ}$, IV).

$7 \mathrm{CF}$, art. 3: construção de uma sociedade livre, justa e solidária, garantia do desenvolvimento nacional, erradicação da pobreza e da marginalização, redução das desigualdades sociais e regionais, promoção do bem de todos, sem preconceitos de origem, raça. sexo, cor, idade e quaisquer outras formas de discriminação.

72 E.g., soberania, independência, autodeterminação dos povos, não-intervenção e igualdade entre os Estados (art. 4, I, III, IV, V), defesa da paz, de solução pacífica dos conflitos e repúdio ao terrorismo e ao racismo (art. 4, VI, VII e VIII), prevalência do direitos humanos (art. 4, II).

73 Exemplos de princípios gerais são: legalidade (art. $5^{\circ}$, II), liberdade (art. $5^{\circ}$, II e diversos incisos do art. $5^{\circ}$, como IV, VI, IX, XIII, XIV, XV, XVI, XVII, etc), isonomia (art. $5^{\circ}$, caput e inciso I), autonomia estadual e municipal (art. 18), acesso ao Judiciário (art. $5^{\circ}, \mathrm{XXXV}$ ), juiz natural (art. $5^{\circ}$, XXXVII e LIII), devido processo legal (art. $5^{\circ}$, LIV). O elenco, naturalmente, não é exaustivo e comportaria significativa ampliação, de acordo com o ponto de observação de cada um. Há características peculiares a esses princípios, em contraste com os que se identificam como fundamentais. Notadamente, não têm caráter organizatório do Estado, mas sim limitativo de seu poder, resguardando situações individuais.

74 Robert Alexy, Colisão e ponderação como problema fundamental da dogmática dos direitos fundamentais, cit., p. 10: "As colisões dos direitos fundamentais acima mencionadas devem ser consideradas segundo a teoria dos princípios como uma colisão de princípios. O processo para a solução de colisões de princípios é a ponderação." 
se irradiam limitadamente, mas no seu âmbito de atuação são supremos. Por vezes, são mero detalhamento dos princípios gerais, como os princípios da legalidade tributária ou da reserva legal em matéria penal. Outras vezes são autônomos, como o princípio da anterioridade em matéria tributária ou o do concurso público para provimento de cargos na administração pública. Há princípios especiais em domínios diversos, como os da Administração Pública ${ }^{75}$, organização dos Poderes ${ }^{76}$, tributação e orçamento ${ }^{77}$, ordem econômica ${ }^{78}$ e ordem social ${ }^{79}$.

\section{Modalidades de eficácia dos princípios ${ }^{80}$}

Examina-se, nesse tópico, os diferentes comportamentos exigíveis com base nos princípios matérias. A eficácia é um atributo associado às normas e consiste na consequêencia jurídica que deve resultar de sua observância, podendo ser exigida judicialmente se necessário. A percepção de que também aos princípios constitucionais deve ser reconhecida eficácia jurídica é fenômeno relativamente recente, em comparação com as regras. De toda sorte, a doutrina tem procurado expandir a capacidade normativa dos princípios através de dois movimentos: aplicando, com as adaptações necessárias, a modalidade convencional de eficácia jurídica das regras também aos princípios - é a eficácia positiva ou simétrica referida abaixo - e desenvolvendo modalidades diferenciadas, adaptadas às características próprias dos princípios - de que são exemplo as três outras modalidades de eficácia apresentadas na seqüuencia ${ }^{81}$.

75 E.g., legalidade administrativa (art. 37, caput), impessoalidade (art. 37, caput), moralidade (art. 37, caput), publicidade (art. 37, caput), concurso público (art. 37, II) e prestação de contas (arts. 70 , parágrafo único, 34 , VII, $d$, e 35, II);

76 E.g., majoritário (arts. 46 e $77, \S 2^{\circ}$ ), proporcional (arts. 45 , e $58, \S 1^{\circ}$ ), publicidade e motivação das decisōes judiciais e administrativas (art. 93, IX e X), independência e imparcialidade dos juízes (arts. 95 e 96) e subordinação das Forças Armadas ao poder civil (art. 142).

77 E.g., capacidade contributiva (art. $145, \S 1^{\circ}$ ), legalidade tributária (art. 150, I), isonomia tributária (art. 150, II), anterioridade da lei tributária (art. 150, III), imunidade recíproca das pessoas jurídicas de direito público (art. 150, VI, a), anualidade orçamentária (art. 165, III), universalidade do orçamento (art. $165, \S 5^{\circ}$ ) e exclusividade da matéria orçamentária (art. $165, \S 8^{\circ}$ ).

78 E.g., garantia da propriedade privada (art. 170, II), função social da propriedade (art. 170, III), livre concorrência (art. 170, IV), defesa do consumidor (art. 170, V) e defesa do meio ambiente (art. 170, VI).

79 E.g., gratuidade do ensino público (art. 206. IV), autonomia universitária (art. 207) e autonomia desportiva (art. 217, I).

80 BARCELLOS, Ana Paula de. A eficácia jurídica dos princípios. O princípio da dignidade da pessoa humana, 2002, p. 59 e ss.

81 BONAVIDES, Paulo. Curso de direito constitucional, 1999, p. 254; Luís Roberto BARROSO, Interpretação e aplicação da Constituição, 2000, p. 146; e Ruy Samuel ESPÍNDOLA, Conceito de princípios constitucionais, 1999. 


\section{III.1. Eficácia positiva ou simétrica}

Eficácia jurídica positiva ou simétrica é o nome pelo qual se convencionou designar a eficácia associada à maioria das regras. Embora sua enunciação seja bastante familiar, a aplicação da eficácia positiva aos princípios ainda é uma construção recente. Seu objetivo, no entanto, seja quando aplicável a regras, seja quando aplicável a princípios, é o mesmo: reconhecer àquele que seria beneficiado pela norma, ou simplesmente àquele que deveria ser atingido pela realização de seus efeitos, direito subjetivo a esses efeitos, de modo que seja possível obter a tutela específica da situação contemplada no texto legal. Ou seja: se os efeitos pretendidos pelo princípio constitucional não ocorreram - tenha a norma sido violada por ação ou por omissão - a eficácia positiva ou simétrica pretende assegurar ao interessado a possibilidade de exigi-los diretamente, na via judicial se necessário. Como se vê, um pressuposto para o funcionamento adequado dessa modalidade de eficácia é a identificação precisa dos efeitos pretendidos por cada princípio constitucional. A este ponto se retornará adiante.

\section{III.2. Eficácia interpretativa}

A eficácia interpretativa significa, muito singelamente, que se pode exigir do Judiciário que as normas de hierarquia inferior sejam interpretadas de acordo com as de hierarquia superior a que estão vinculadas. Isso acontece, e.g., entre leis e seus regulamentos e entre as normas constitucionais e a ordem infraconstitucional como um todo. A eficácia interpretativa poderá operar também dentro da própria Constituição, em relação aos princípios; embora eles não disponham de superioridade hierárquica sobre as demais normas constitucionais, é possível reconhecer-lhes uma ascendência axiológica sobre o texto constitucional em geral, até mesmo para dar unidade e harmonia ao sistema ${ }^{82}$. A eficácia dos princípios constitucionais, nessa acepção, consiste em orientar a interpretação das regras em geral (constitucionais e infraconstitucionais), para que o intérprete faça a opção, dentre as possíveis exegeses para o caso, por aquela que realiza melhor o efeito pretendido pelo princípio constitucional pertinente.

\section{III.3. Eficácia negativa}

A eficácia negativa ${ }^{83}$, por sua vez, autoriza que sejam declaradas inválidas todas

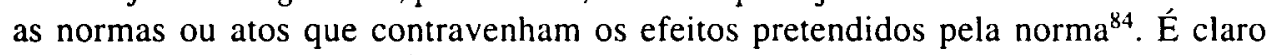

82 SILVA, José Afonso da. Aplicabilidade das normas constitucionais, 1998, p. 157 e ss; e Luís Roberto Barroso, Interpretação e aplicação da Constituição, 2000, p. 141 e ss.

83 Sobre essa modalidade de eficácia, vejam-se: Jorge MIRANDA, Manual de direito constitucional, vol. II, 1990, p. 220 e ss., e German J. Bidart Campos, La interpretacion y el control constitucionales en la jurisdiccion constitucional, 1987, p. 238 e ss.; Celso Antônio BANDEIRA DE MELLO, Eficácia das normas constitucionais sobre justiça social, RDP n 57-58/243 e ss.; e José Afonso da SILVA, Aplicabilidade das normas constitucionais, 1998, p. 158 e ss.

84 No caso das normas, elas poderão ser consideradas revogadas ou não recepcionadas, caso anteriores à promulgação da Constituição. 
que para identificar se uma norma ou ato viola ou contraria os efeitos pretendidos pelo princípio constitucional é preciso saber que efeitos são esses. Como já referido, os efeitos pretendidos pelos princípios podem ser relativamente indeterminados a partir de um certo núcleo; é a existência desse núcleo, entretanto, que torna plenamente viável a modalidade de eficácia jurídica negativa. Imagine-se um exemplo. Uma determinada empresa rural prevê, no contrato de trabalho de seus empregados, penas corporais no caso de descumprimento de determinadas regras. Ou sanções como privação de alimentos ou proibição de avistar-se com seus familiares. Afora outras especulações, inclusive de natureza constitucional, não há dúvida de que a eficácia negativa do princípio da dignidade da pessoa humana conduziria tal norma à invalidade. É que nada obstante a relativa indeterminação do conceito de dignidade humana, há consenso de que em seu núcleo central deverão estar a rejeição às penas corporais, à fome compulsória e ao afastamento arbitrário da família.

\section{III.4. Eficácia vedativa do retrocesso}

A vedação do retrocesso, por fim, é uma derivação da eficácia negativa ${ }^{85}$, particularmente ligada aos princípios que envolvem os direitos fundamentais. Ela pressupõe que esses princípios sejam concretizados através de normas infraconstitucionais (isto é: freqüentemente, os efeitos que pretendem produźir são especificados por meio da legislação ordinária) e que, com base no direito constitucional em vigor, um dos efeitos gerais pretendidos por tais princípios é a progressiva ampliação dos direitos fundamentais ${ }^{86}$. Partindo desses pressupostos, o que a vedação do retrocesso propõe se possa exigir do Judiciário é a invalidade da revogação de normas que, regulamentando o princípio, concedam ou ampliem direitos fundamentais, sem que a revogação em questão seja acompanhada de uma política substitutiva ou equivalente. Isto é: a invalidade, por inconstitucionalidade, ocorre quando se revoga uma norma infraconstitucional concessiva de um direito, deixando um vazio em seu $\operatorname{lugar}^{87}$. Não se trata, é bom observar, da substituição de uma forma de atingir o fim constitucional por outra, que se entenda mais apropriada. A questão que se põe é a da revogação pura e simples da norma infraconstitucional, pela qual o legislador esvazia o comando constitucional, exatamente como se dispusesse contra ele diretamente ${ }^{88}$.

85 A vedação do retrocesso enfrenta ainda alguma controvérsia, especialmente quanto à sua extensão. Para uma visão crítica dessa construção, confira-se José Carlos Vieira de ANDRADE, Os direitos fundamentais na Constituição portuguesa de 1976, 1998, p. 307/311.

$86 \mathrm{Na}$ Carta brasileira, esse propósito fica claro tanto no art. $5^{\circ}, \S 2^{\circ}$, como no caput do art. $7^{\circ}$.

87 ROCHA, Cármen Lucia Antunes. O principio da dignidade da pessoa humana e a exclusão social, IP 4/41: “De se atentar que prevalece, hoje, no direito constitucional, o princípio do não-retrocesso, segundo o qual as conquistas relativas aos direitos fundamentais não podem ser destruídas, anuladas ou combalidas (...)".

88 Sobre o tema, v. J. J. Gomes CANOTILHO, Direito constitucional e teoria da constituição, 1999, p. 327. 
A atribuição aos princípios constitucionais das modalidades de eficácia descritas acima tem contribuído decisivamente para a construção de sua normatividade. Entretanto, como indicado em vários momentos no texto, essas modalidades de eficácia somente podem produzir o resultado a que se destinam se forem acompanhadas da identificação cuidadosa dos efeitos pretendidos pelos princípios e das condutas que realizem o fim indicado pelo princípio ou que preservem o bem jurídico por ele protegido.

\section{Algumas aplicą̧ōes concretas dos princípios materiais}

Não é possível, à vista do objetivo do presente estudo e das circunstâncias de tempo e espaço. analisar o sentido, alcance, propriedades e particularidades de cada uma das categorias e espécies de princípios assinalados acima. Nem tampouco investigar o núcleo no qual cada um deles operará como regra e o espaço remanescente onde deverão ser ponderados entre si. Mas para ilustração, antes do desfecho das idéias desenvolvidas, faz-se o destaque da aplicação concreta dos princípios da dignidade humana ${ }^{89} \mathrm{e}$ do devido processo legal ${ }^{90}$, concluindo com breve apreciação do papel desempenhado pelo princípio da razoabilidade no âmbito do sistema.

O princípio da dignidade da pessoa humana identifica um espaço de integridade moral a ser assegurado a todas as pessoas por sua só existência no mundo. É um respeito à criação, independentemente da crença que se professe quanto à sua origem. A dignidade relaciona-se tanto com a liberdade e valores do espírito como com as condições materiais de subsistência. Não tem sido singelo, todavia, o esforço para permitir que o princípio transite de uma dimensão ética e abstrata para as motivações racionais e fundamentadas das decisões judiciais. Partindo da premissa anteriormente estabelecida de que os princípios, a despeito de sua indeterminação a partir de um certo ponto, possuem um núcleo no qual operam como regras, tem-se sustentado que no tocante ao princípio da dignidade da pessoa humana esse núcleo é repre-

89 BARCELLOS. Ana Paula de. A eficácia jurídica dos princípios constitucionais: o princípio da dignidade da pessoa humana, 2002; Ingo Wolfgang SARLET. Dignidade da pessoa humana $e$ direitos fundamentais, 2002: Fernando Ferreira dos SANTOS, O principio constitucional da dignidade da pessoa humana, 1999; Cleber Francisco ALVES, O princípio constitucional da dignidade da pessoa humana: o enfoque da dourrina social da lgreja, 2001: Fábio Konder COMPARATO. A afirmação histórica dos direitos humanos. 2003: Alexandre de MORAES, Direitos humanos fundamentais, 2002: Lúcia de Barros Freitas de ALVARENGA, Direitos humanos, dignidade e erradicação da pobreza: uma dimensão hermenêutica para a realização constitucional, 1998; Joaquim B. Barbosa GOMES, $O$ poder de policia e o princípio da dignidade da pessoa humana na jurisprudência francesa (ADVSJ 12-96/17); Cármen Lúcia Antunes ROCHA, O princípio da dignidade da pessoa humana e a exclusão social (IP 4/23); Antonio Junqueira de AZEVEDO, Caracterização jurídica da dignidade da pessoa humana (RT 797:11); Valter Shuenquener de ARAÚJO, Hierarquização axiológica de princípios - relativizaçāo do princípio da dignidade da pessoa humana e o postulado da preservação do contrato social (RPGERJ 55/82).

90 GRINOVER, Ada Pellegrini. Antônio Carlos de Araújo CINTRA e Cândido Rangel DINAMARCO, Teoria geral do processo, 1998, p. 56. 
sentado pelo mínimo existencial. Embora existam visões mais ambiciosas do alcance elementar do princípio ${ }^{91}$, há razoável consenso de que ele inclui pelo menos os direitos à renda mínima, saúde básica, educação fundamental e acesso à justiça ${ }^{92}$.

A percepção da centralidade do princípio chegou à jurisprudência dos tribunais superiores, onde já se assentou que "a dignidade da pessoa humana, um dos fundamentos do Estado democrático de direito, ilumina a interpretação da lei ordinária" 93 . De fato, tem ela servido de fundamento para decisões de alcance diverso, como o fornecimento compulsório de medicamentos pelo Poder Público ${ }^{94}$, a nulidade de cláusula contratual limitadora do tempo de internação hospitalar ${ }^{95}$, a rejeição da prisão por dívida motivada pelo não pagamento de juros absurdos ${ }^{96}$, o levantamento do FGTS para tratamento de familiar portador do vírus $\mathrm{HIV}^{97}$, dentre muitas outras. Curiosamente, no tocante à sujeição do réu em ação de investigação de paternidade ao exame compulsório de DNA, há decisões em um sentido ${ }^{98}$ e noutro ${ }^{99}$, com invocação do princípio da dignidade humana.

Quanto ao princípio do devido processo legal, embora seus corolários mais diretos já estejam analiticamente previstos no texto constitucional e na legislação infraconstitucional, tem sido aplicado de modo a gerar a exigibilidade de outros comportamentos não explicitados. O princípio foi invocado para considerar, com base nele, inválido o oferecimento de denúncia por outro membro do Ministério Público, após anterior arquivamento do inquérito policial ${ }^{100}$, entender ilegítima a anulação de processo administrativo que repercutia sobre interesses individuais sem observância do contraditório ${ }^{101}$, reconhecer haver constrangımento ilegal no uso de algemas quando as condições do réu não ofereciam perigo ${ }^{102}$, para negar extradição à vista da perspectiva de inobservância do devido processo legal no país requerente ${ }^{103}$ e para determinar fosse ouvida a parte contrária na hipótese de embargos de declaração opostos com pedido de efeitos modificativos, a despeito de não haver previsão nesse sentido na legislação ${ }^{104}$.

91 Como, por exemplo, a que inclui no mínimo existencial o atendimento às necessidades que deveriam ser supridas pelo salário mínimo, nos termos do art. $7^{\circ}, I V$, da Constituição, a saber: moradia, alimentação, educação, saúde, lazer, vestuário, higiene, transporte e previdência social.

92 BARCELLOS, Ana Paula de. A eficácia jurídica dos princípios constitucionais. O princípio da dignidade da pessoa humana, 2002, p. 247 e ss.

93 STJ, HC 9.892-RJ, DJ 26.3.01, Rel. orig. Min. Hamilton Carvalhido, Rel. para ac. Min. Fontes de Alencar.

94 STJ, ROMS 11.183-PR, DJ 4.9.00, Rel. Min. José Delgado.

95 TJSP, AC 110.772-4/4-00, ADV 40-01/636, n 98859. Rel. Des. O. Breviglieri.

96 STJ, HC 12547/DF, DJ 12.2.01, Rel. Min. Ruy Rosado de Aguiar.

97 STJ, REsp. 249026-PR, DJ 26.06.00, Rel. Min. José Delgado.

98 STF, HC 71.373-RS, DJ 10.11.94, Rel. Min. Marco Aurélio.

99 TJSP, AC 191.290-4/7-0, ADV 37-01/587, n. 98580, Rel. Des. A. Germano.

100 STJ, HC 6.802-RJ, RT 755/569, Rel. Min. Vicente Leal.

10I STF, AI 199.620-55, DJ 14.8.97.

102 TJRS, RT 785/692, HC 70.001.561.562, Rel. Des. Silvestre Jasson Ayres Torres.

103 STF, Extr. 633-China, DJ 6.4.01, Rel. Min. Celso de Mello.

104 STF, AI 327728-SP, DJ 19.12.01, Rel. Min. Nelson Jobim. 
Por fim, merece uma nota especial o princípio da razoabilidade, que tem sido fundamento de decidir em um conjunto abrangente de situações, por parte de juízes e tribunais, inclusive e especialmente o Supremo Tribunal Federal. Com base nele tem-se feito o controle de legitimidade das desequiparaçôes entre pessoas, de vantagens concedidas a servidores públicos ${ }^{105}$, de exigências desmesuradas formuladas pelo Poder Público ${ }^{106}$ ou de privilégios concedidos à Fazenda Pública ${ }^{107}$. O princípio, referido na jurisprudência como da proporcionalidade ou razoabilidade (v. supra), é por vezes utilizado como um parâmetro de justiça - e, nesses casos, assume uma dimensão material —, porém, mais comumente, desempenha papel instrumental na interpretação de outras normas. Confira-se a demonstração do argumento.

O princípio da razoabilidade faz parte do processo intelectual lógico de aplicação de outras normas, ou seja, de outros princípios e regras. Por exemplo: ao aplicar uma regra que sanciona determinada conduta com uma penalidade administrativa, o intérprete deverá agir com proporcionalidade. levando em conta a natureza e a gravidade da falta. O que se estará aplicando é a norma sancionadora, sendo o princípio da razoabilidade um instrumento de medida. O mesmo se passa quando ele é auxiliar do processo de ponderação. Ao admitir o estabelecimento de uma idade máxima ou de uma altura mínima para alguém prestar concurso para determinado cargo público ${ }^{108}$, o que o Judiciário faz é interpretar o princípio da isonomia, de acordo com a razoabilidade: se o meio for adequado, necessário e proporcional para realizar um fim legítimo, deve ser considerado válido. Nesses casos, como se percebe intuitivamente, a razoabilidade é o meio de aferição do cumprimento ou não de outras normas ${ }^{109}$.

Uma observação final. Alguns dos exemplos acima envolveram a não aplicação de determinadas regras porque importariam em contrariedade a um princípio ou a um fim constitucional. Essa situação - aquela em que uma regra não é em si inconstitucional, mas em uma determinada incidência produz resultado inconstitu-

105 STF, ADIn 1.158-8-AM, RDA 200/242, Rel. Min. Celso de Mello. A norma legal que concede ao servidor vantagem pecuniária cuja razão de ser se revela absolutamente destituída de causa (gratificação de férias) ofende o princípio da razoabilidade.

106 STF, ADIn 855-2-PR, RDA 194/299. Rel. Min. Sepúlveda Pertence. Viola o princípio da razoabilidade e da proporcionalidade lei estadual que determina a pesagem de botijões de gás à vista do consumidor.

107 STF, ADInMC 1.753-DF, DJ 12.6.98. Rel. Min. Sepúlveda Pertence.

108 STF, RE 140.889-MS. DJ 15.12.00. Rel. Min. Marco Aurélio. V. tb. STF. RE 150.455-MS, DJ 7.5.99, Rel. Min. Marco Aurélio.

109 No mesmo sentido, v. Humberto ÁVILA, Teoria dos principios (da definição à aplicação dos principios juridicos), cit., p. 71: "[N]o caso em que o Supremo Tribunal Federal declarou inconstitucional uma lei estadual que determinava a pesagem de botijōes de gás à vista do consumidor, o princípio da livre iniciativa foi considerado violado, por ter sido restringido de modo desnecessário e desproporcional. Rigorosamente, não é a proporcionalidade que foi violada, mas o princípio da livre iniciativa, na sua inter-relação horizontal com o princípio da defesa do consumidor, que deixou de ser aplicado adequadamente." 
cional - começa a despertar interesse da doutrina ${ }^{110}$. O fato de uma norma ser constitucional em tese não exclui a possibilidade de ser inconstitucional in concreto, à vista da situação submetida a exame. Portanto, uma das consequiências legítimas da aplicação de um princípio constitucional poderá ser a não aplicação da regra que o contravenha ${ }^{111}$.

Mas este já é o começo de uma outra história.

\section{CONCLUSÃO}

Ao final dessa exposição, é possível compendiar algumas das principais idéias desenvolvidas nas proposições que se seguem.

I. A interpretação constitucional tradicional assenta-se em um modelo de regras, aplicáveis mediante subsunção, cabendo ao intérprete o papel de revelar o sentido das normas e fazê-las incidir no caso concreto. Os juizos que formula são de fato, e não de valor. Por tal razão. não the toca função criativa do Direito, mas apenas uma atividade de conhecimento técnico. Esta perspectiva convencional ainda continua de grande valia na solução de boa parte dos problemas jurídicos, mas nem sempre é suficiente para lidar com as questões constitucionais, notadamente a colisão de direitos fundamentais.

II. A nova interpretação constitucional assenta-se em um modelo de princípios, aplicáveis mediante ponderação, cabendo ao intérprete proceder à interação entre fato e norma e realizar escolhas fundamentadas, dentro das possibilidades e limites oferecidos pelo sistema jurídico, visando à solução justa para o caso concreto. Nessa perspectiva pós-positivista do Direito, são idéias essenciais a normatividade dos princípios, a ponderação de valores e a teoria da argumentação.

III. Pós-positivismo é a designação provisória e genérica de um ideário difuso, no qual se incluem o resgate dos valores, a distinção qualitativa entre princípios e regras, a centralidade dos direitos fundamentais e a reaproximação entre o Direito e a Ética. A estes elementos devem-se agregar, em um país como o Brasil, uma perspectiva do Direito que permita a superação da ideologia da desigualdade e a incorporação à cidadania da parcela da população deixada à margem da civilização e do consumo. É preciso transpor a fronteira da reflexão filosófica, ingressar na prática jurisprudencial e produzir efeitos positivos sobre a realidade.

110 Normalmente, na linha da doutrina de DWORKIN e ALEXY, a ponderação se dá entre principios. Trata-se aqui, no entanto, de uma hipótese menos típica, mas possível, de ponderação entre princípio e regra. Usualmente, a regra já espelhará uma ponderação feita pelo legislador e deverá ser aplicada em toda a sua extensão, desde que seja válida. Mas a ponderação feita em tese pelo legislador, assim como a pronúncia em tese de constitucionalidade pelo STF, pode não realizar a justiça do caso concreto.

11 BARROSO, Luís Roberto. Interpretaçāo e aplicação da Constituição, post scriptum, 2003. Para uma importante reflexão sobre o tema, v. Ana Paula Oliveira ÁVILA, Razoabilidade, proteção do direito fundamental à saúde e antecipação de tutela contra a Fazenda Pública, Ajuris 86/361. 
IV. A ponderação de valores, interesses, bens ou normas consiste em uma técnica de decisão jurídica utilizável nos casos difíceis, que envolvem a aplicação de princípios (ou, excepcionalmełte, de regras) que se encontram em linha de colisão, apontando soluções diversas e contraditórias para a questão. O raciocínio ponderativo, que ainda busca parâmetros de maior objetividade, inclui a seleção das normas e dos fatos relevantes, com a atribuição de pesos aos diversos elementos em disputa, em um mecanismo de concessões recíprocas que procura preservar, na maior intensidade possível, os valores contrapostos.

V. A teoria da argumentação tornou-se elemento decisivo da interpretação constitucional, nos casos em que a solução de um determinado problema não se encontra previamente estabelecida pelo ordenamento, dependendo de valorações subjetivas a serem feitas à vista do caso concreto. Cláusulas de conteúdo aberto, normas de princípio e conceitos indeterminados envol vem o exercício de discricionariedade por parte do intérprete. Nessas hipóteses, o fundamento de legitimidade da atuação judicial transfere-se para o processo argumentativo: a demonstração racional de que a solução proposta é a que mais adequadamente realiza a vontade constitucional.

VI. A interpretação constitucional serve-se das categorias da interpretação jurídica em geral, inclusive os elementos gramatical, histórico, sistemático e teleológico. Todavia, as especificidades das normas constitucionais levaram ao desenvolvimento de um conjunto de princípios específicos de interpretação da Constituição, de natureza instrumental, que funcionam como premissas conceituais, metodológicas ou finalísticas da aplicação das normas que vão incidir sobre a relação jurídica de direito material. Estes princípios instrumentais são os da supremacia da Constituição, da presunção de constitucionalidade, da interpretação conforme a Constituição, da unidade, da razoabilidade-proporcionalidade e da efetividade.

VII. Os princípios constitucionais materiais classificam-se, em função do seu status e do grau de irradiação, em fundamentais, gerais e setoriais. Dentre as modalidades de eficácia dos princípios, merecem destaque a interpretativa - que subordina a aplicação de todas as normas do sistema jurídico aos valores e fins neles contidos - e a negativa, que paralisa a incidência de qualquer norma que seja com eles incompatível. É possível acontecer de uma norma ser constitucional no seu relato abstrato, mas revelar-se inconstitucional em uma determinada incidência, por contrariar o próprio fim nela abrigado ou algum princípio constitucional.

VIII. A jurisprudência produzida a partir da Constituição de 1988 tem progressivamente se servido da teoria dos princípios, da ponderação de valores e da argumentação. A dignidade da pessoa humana começa a ganhar densidade jurídica e a servir de fundamento para decisões judiciais. Ao lado dela, o princípio instrumental da razoabilidade funciona como a justa medida de aplicação de qualquer norma, tanto na ponderação feita entre princípios quanto na dosagem dos efeitos das regras.

IX. A Constituição de 1988 tem sido valiosa aliada do processo histórico de superação da ilegitimidade renitente do poder político, da atávica falta de efetividade das normas constitucionais e da crônica instabilidade institucional brasileira. Sua 
interpretação criativa, mas comprometida com a boa dogmática jurídica, tem se beneficiado de uma teoria constitucional de qualidade e progressista. No Brasil, o discurso jurídico, para desfrutar de legitimidade histórica, precisa ter compromisso com a transformação das estruturas, a emancipação das pessoas, a tolerância política e o avanço social. 